\author{
Elżbieta Papińska \\ Katedra Geografii Fizycznej \\ Wydział Nauk Geograficznych, Uniwersytet Łódzki
}

Artykuł wpłynął do redakcji 08.12.2013; po recenzjach zaakceptowany 20.12.2013

\title{
ALASKA JAKO PRZYKLAD OBSZARU RECEPCJI TURYSTYCZNEJ
}

\section{ALASKA AS AN EXAMPLE OF TOURIST RECEPTION AREA}

Stan Alaska położony jest na północnym-zachodzie Ameryki Północnej. Zajmuje on 1717854 km² powierzchni, którą zamieszkuje 731449 mieszkańców (2012 r.). Gęstość zaludnienia jest niewielka i wynosi zaledwie $0,5 \mathrm{os} / \mathrm{km}^{2}$. Wpływ na tę sytuację mają przede wszystkim stosunkowo niekorzystne warunki naturalne, z których najważniejszy wpływ mają warunki klimatyczne, wieloletnia zmarzlina i ukształtowanie terenu.

Różnorodność krajobrazu będąca efektem ogromnego zróżnicowania form rzeźby, zdecydowała, iż na terenie Alaski utworzono 8 parków narodowych (Denali National Park, Gates of the Arctic National Park, Glacier Bay National Park, Katmai National Park, Kenai Fjords National Park, Kobuk Valley National Park, Lake Clark National Park, Wrangell-St. Elias National Park), utworzono pomniki narodowe oraz obszary o niższej randze ochrony. Każdy z tych obszarów stanowi magnes przyciągający rzesze turystów z USA i z całego świata, gdyż znajdują się tu niepowtarzalne formy krajobrazu, jak lodowce, aktywne wulkany, fiordy, wysokie góry. Obszary te mają ogromne znaczenie dla rozwoju turystyki w USA, a tym samym dla gospodarki. Rocznie tylko Alaskę odwiedza ok. 2 mln osób.

Słowa kluczowe: Alaska, walory przyrodnicze, parki narodowe, turystyka

\section{WPROWADZENIE}

Alaska położona jest w północno-zachodniej części Ameryki Północnej. Jej powierzchnia wynosi $1717854 \mathrm{~km}^{2}$, co klasuje ją na pierwszym miejscu pod względem powierzchni wśród wszystkich stanów USA. Alaska jest 49 stanem USA, przyłączonym do Unii dopiero 3 stycznia 1959 roku. Terytorium Alaski rozciąga się między $51^{\circ} 20^{\prime} \mathrm{N}$ a $71^{\circ} 23^{\prime} \mathrm{N}(2285 \mathrm{~km})$ oraz między $130^{\circ} \mathrm{W}$ 
i $172^{\circ}$ E (3 $639 \mathrm{~km}$ ). To ogromne terytorium zamieszkiwało w 2012 r. 731449 osób, co dawało najmniejszą gęstość zaludnienia w USA, poniżej $0,5 \mathrm{os} / \mathrm{km}^{2}$. Nie odzwierciedla to jednak faktycznego rozmieszczenia ludności na tym terytorium, gdyż prawie 40\% ludności Alaski mieszka w Anchorage. Stolicę stanu Juneau zamieszkuje 32,5 tys. osób. Rzeczywista gęstość zaludnienia jest więc jeszcze niższa.

Stosunkowo niewielka liczba ludności zamieszkująca Alaskę wynika przede wszystkim z trudnych warunków przyrodniczych, jakie występują na tym obszarze. Położenie w wysokich szerokościach geograficznych wpływa na warunki klimatyczne, które na większości obszaru są mało korzystne dla człowieka. Dominuje klimat umiarkowany chłodny, na wybrzeżu morski, w centrum półwyspu kontynentalny, zaś w strefie między wybrzeżem a centrum Alaski, przejściowy (wg klasyfikacji klimatycznej W. Okołowicza 1969). Północna część Alaski znajduje się w strefie klimatu okołobiegunowego, subpolarnego (rys. 1). Trudne warunki klimatyczne ilustrują dane zawarte w tab. 1 i 2, które przedstawiają zróżnicowanie termiczne tego obszaru.

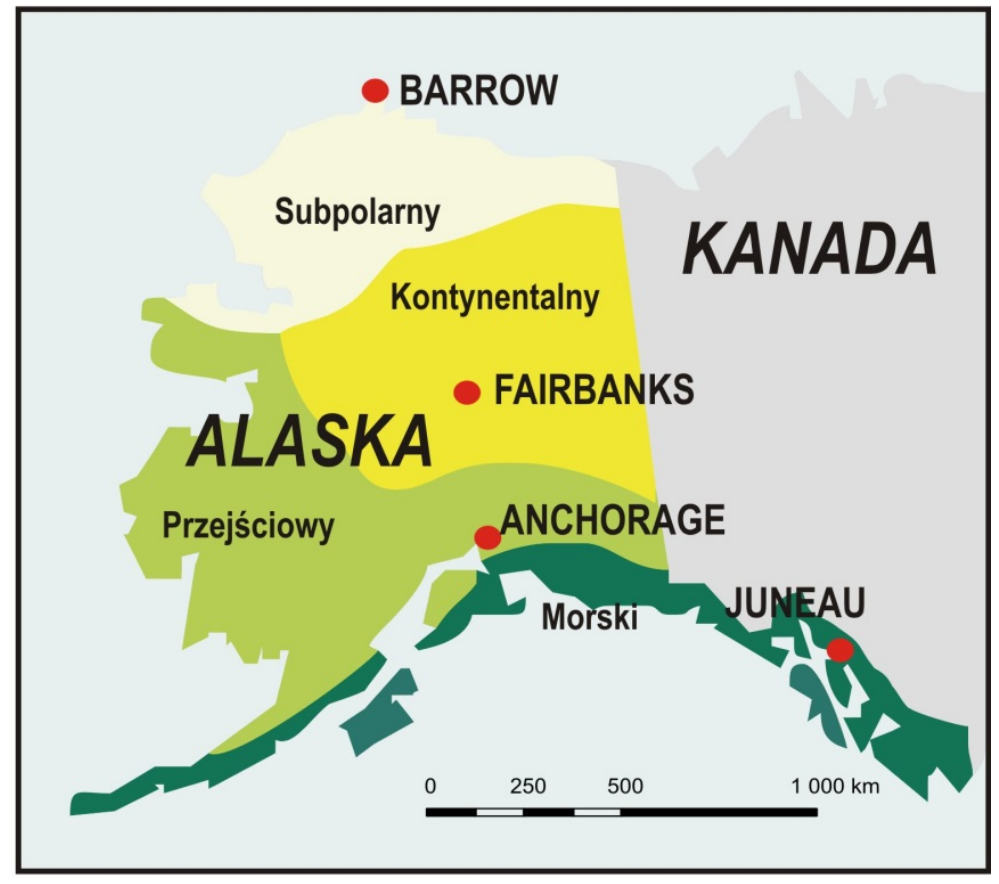

Rys. 1. Rozmieszczenie stacji klimatycznych na tle typów klimatu Alaski Źródło: opracowanie na podstawie http://commons.wikimedia.org/wiki/File: Alaska_climate_regions_USGS.gif

Fig. 1. Distribution of climate stations against the background of Alaska's climate types Source: http://commons.wikimedia.org/wiki/File:Alaska_climate_regions_USGS.gif 
Tab. 1

Temperatury maksymalne i minimalne na terytorium Alaski

Maximum and minimum temperatures in the territory of Alaska

\begin{tabular}{|l|c|c|r|r|r|r|r|r|r|r|r|c|}
\hline Miesiąc & I & II & III & IV & V & VI & VII & VIII & IX & X & XI & XII \\
\hline $\begin{array}{l}\text { Max } \\
\text { temp. }\left({ }^{\circ} \mathrm{C}\right)\end{array}$ & 17 & 19 & 21 & 28 & 33 & 38 & 37 & 37 & 31 & 23 & 19 & 18 \\
\hline Rok & 1981 & 1992 & 1936 & 1976 & 1960 & 1915 & 1976 & 1976 & 1940 & 1969 & 1970 & 1934 \\
\hline $\begin{array}{l}\text { Min } \\
\text { temp. }\left({ }^{\circ} \mathrm{C}\right)\end{array}$ & -62 & -59 & -56 & -46 & -32 & -18 & -9 & -13 & -25 & -46 & -52 & -58 \\
\hline Rok & 1971 & 1947 & 1971 & 1986 & 1992 & 1967 & 1924 & 1922 & 1970 & 1975 & 1935 & 1999 \\
\hline
\end{tabular}

Źródło: http://www.infoplease.com/ipa/A0930150.html, dostęp: 03.12.2013.

Source: http://www.infoplease.com/ipa/A0930150.html, access: 03.12.2013.

Dodatkową barierą dla rozwoju osadnictwa, wynikającą z położenia geograficznego w wysokich szerokościach geograficznych jest duża dysproporcja w długości trwania dnia. Latem na znacznym obszarze dzień trwa ponad 18-20 godzin, za kołem podbiegunowym panuje dzień polarny, zaś zimą obserwujemy zjawisko odwrotne. Mała liczba godzin ze słońcem lub ich brak, bardzo niekorzystnie wpływa na psychikę człowieka powodując często depresję.

Tab. 2

Dane klimatyczne (1981-2010) dla stacji: Barrow - klimat subpolarny; Fairbanks klimat umiarkowany chłodny, kontynentalny; Anchorage - klimat umiarkowany chłodny, przejściowy; Juneau - klimat umiarkowany chłodny, morski

Climate data (1981-2010) for the station: Barrow - sub-polar; Fairbanks - continental;

Anchorage - transitional; Juneau - maritime

\begin{tabular}{|l|c|c|c|c|c|c|c|c|c|c|c|c|c|}
\hline Miesiąc & I & II & III & IV & V & VI & VII & VIII & IX & X & XI & XII & Rok \\
\hline 1 & 2 & 3 & 4 & 5 & 6 & 7 & 8 & 9 & 10 & 11 & 12 & 13 & 14 \\
\hline \multicolumn{10}{|c|}{ Max temp. $\left({ }^{\circ} \mathbf{C}\right)$} \\
\hline Barrow & 2 & 3 & 1 & 6 & 8 & 22 & 26 & 24 & 17 & 6 & 4 & 1 & 26 \\
\hline Fairbanks & 11 & 10 & 13 & 24 & 32 & 36 & 37 & 34 & 29 & 22 & 12 & 14 & 37 \\
\hline Anchorage & 13 & 14 & 13 & 22 & 28 & 29 & 29 & 29 & 23 & 18 & 17 & 12 & 29 \\
\hline Juneau & 14 & 14 & 16 & 23 & 28 & 31 & 32 & 31 & 29 & 20 & 18 & 15 & 32 \\
\hline \multicolumn{10}{|c|}{ Średnia dobowa $\left({ }^{\circ} \mathbf{C}\right)$} \\
\hline Barrow & $-25,2$ & $-25,7$ & $-24,7$ & $-16,8$ & $-6,1$ & 2 & 4,9 & 3,9 & 0,1 & $-8,2$ & $-17,4$ & $-22,1$ & $-11,27$ \\
\hline Fairbanks & $-23,4$ & $-19,8$ & $-11,7$ & $-0,7$ & 9,2 & 15,4 & 16,9 & 13,8 & 7,5 & $-3,8$ & $-16,3$ & $-21,4$ & $-2,8$ \\
\hline Anchorage & $-9,5$ & $-7,4$ & $-3,5$ & 2,1 & 8,1 & 12,4 & 14,7 & 13,5 & 9,1 & 1,4 & $-6,0$ & $-8,7$ & 2,2 \\
\hline Juneau & $-2,1$ & $-1,1$ & 1 & 4,9 & 9,2 & 12,5 & 13,8 & 13,2 & 10 & 5,8 & 1 & $-1,2$ & 5,58 \\
\hline \multicolumn{10}{|c|}{ Min temp. $\left({ }^{\circ} \mathbf{C}\right)$} \\
\hline Barrow & -47 & -49 & -47 & -41 & -28 & -16 & -6 & -7 & -17 & -36 & -40 & -48 & -49 \\
\hline Fairbanks & -54 & -50 & -49 & -36 & -18 & -3 & -1 & -7 & -16 & -33 & -48 & -52 & -54 \\
\hline Anchorage & -37 & -39 & -31 & -26 & -17 & -2 & 1 & -1 & -7 & -21 & -29 & -38 & -39 \\
\hline Juneau & -30 & -30 & -26 & -14 & -4 & -1 & 2 & -3 & -5 & -12 & -21 & -29 & -30 \\
\hline
\end{tabular}


Tab. 2 (ciąg dalszy)

\begin{tabular}{|c|c|c|c|c|c|c|c|c|c|c|c|c|c|}
\hline 1 & 2 & 3 & 4 & 5 & 6 & 7 & 8 & 9 & 10 & 11 & 12 & 13 & 14 \\
\hline \multicolumn{14}{|c|}{ Opady (mm) } \\
\hline Barrow & 3,5 & 3,3 & 2,3 & 3,8 & 4,6 & 7,6 & 24,9 & 26,7 & 18 & 10,4 & 5,1 & 3,3 & 113,5 \\
\hline Fairbanks & 14,7 & 0,7 & 7,1 & 7,9 & 15,2 & 34,8 & 54,9 & 47,5 & 27,9 & 21,1 & 17,0 & 16,3 & 275,1 \\
\hline Anchorage & 18,8 & 18,5 & 15,2 & 11,9 & 19,3 & 24,4 & 46,5 & 82,3 & 75,7 & 51,6 & 29,7 & 28,4 & 422,3 \\
\hline Juneau & 135,9 & 105,2 & 96,0 & 74,7 & 86,4 & 82,3 & 116,8 & 145,3 & 222 & 218,9 & 156,2 & 48,3 & 587, \\
\hline \multicolumn{14}{|c|}{ Opad śniegu (cm) } \\
\hline Barrow & 7,1 & 7,9 & 5,3 & 7,9 & 6,9 & 1,5 & 0,5 & 2,3 & 11,7 & 22,4 & 15,2 & 8,6 & 97,3 \\
\hline Fairbanks & 25,9 & 21,1 & 12,4 & 7,4 & 2,3 & 0 & 0 & 0 & 4,6 & 27,7 & 32,3 & 30,7 & 164 , \\
\hline Anchorage & 29,2 & 27,9 & 25,4 & 10,4 & 1 & 0 & 0 & 0 & 1 & 19,8 & 33,8 & 43,2 & 191,7 \\
\hline Juneau & 69,6 & 44,2 & 29,5 & 2,8 & 0 & 0 & 0 & 0 & 0 & 2 & 32 & 40,6 & 220,5 \\
\hline
\end{tabular}

Źródło: http://en.wikipedia.org/wiki/Barrow_Alaska; NOAA; NOWData - NOAA Online Weather Data". National Oceanic and Atmospheric Administration. "Average Weather for Fairbanks International Airport, AK". The Weather Channel;

http://en.wikipedia.org/wiki/Fairbanks,_Alaska;

http://www.climatezone.com/climate/unitedstates/alaska/anchorage/index_centigrade.ht m; "Climatological Normals of Juneau", Hong Kong Observatory;

http://en.wikipedia.org/wiki/Juneau,_Alaska. dostęp 03.12.2013.

Source: http://en.wikipedia.org/wiki/Barrow_Alaska; NOAA; NOWData - NOAA Online Weather Data". National Oceanic and Atmospheric Administration. "Average Weather for Fairbanks International Airport, AK". The Weather Channel;

http://en.wikipedia.org/wiki/Fairbanks,_Alaska;

http://www.climatezone.com/climate/unitedstates/alaska/anchorage/index_centigrade.ht m; "Climatological Normals of Juneau", Hong Kong Observatory; http://en.wikipedia.org/wiki/Juneau,_Alaska, access 03.12.2013.

Opisane warunki klimatyczne konserwują wieloletnią zmarzlinę występującą w gruncie, odziedziczoną po okresie plejstoceńskim (rys. 2). Jej obecność niekorzystnie wpływa na możliwości rozwoju infrastruktury niezbędnej do funkcjonowania współczesnych społeczeństw: sieci dróg, wodociągów, kanalizacji, obiektów wielkogabarytowych (np. centra handlowe), czy osiedli mieszkaniowych. Zwiększająca się miąższość wieloletniej zmarzliny w kierunku północnym, znacznie ogranicza możliwości zagospodarowania tych terenów. Latem odmarzająca warstwa czynna wpływa na znaczne zabagnienie terenu, a to powoduje rozwój różnego rodzaju owadów (moskitów, meszek), które są niezwykle uciążliwe dla człowieka. Jedynie południowe wybrzeża pozbawione są zmarzliny, co przekłada się od razu na lepiej rozbudowaną sieć osadniczą.

Rzeźba Alaski jest bardzo urozmaicona. Jej średnia wysokość wynosi 580 m n.p.m. Na jej terenie znajdują się wszystkie jednostki regionalne występujące w Kordylierach. Pasma górskie na obszarze Alaski tworzą wyraźne łuki. Jeden z nich zaczyna się Wyspami Aleuckimi i Górami Aleuckimi. Tworzą je wulkany ciągnące się na długości około $2500 \mathrm{~km}$. Najwyższe z nich osiągają ponad 2000 m n.p.m. Dalej w kierunku północno-wschodnim znajduje kolejne pasmo górskie - góry Alaska (Alaska Range), osiągające długość około 1000 km 
(fot. 1). W górach tych znajduje się najwyższy szczyt Ameryki Północnej Mount McKinley (Denali) 6194 m n.p.m. Łuk zamyka pasmo gór Nadbrzeżnych (Coast Monutains), ciągnących się wzdłuż Pacyfiku na granicy z Kanadą (fot. 2). Na południe od gór Alaska rozciąga się łuk gór wewnętrznych, składający się z pasm: Chugach, Kenai oraz Góry Wrangla, które to charakteryzują się występowaniem czynnych wulkanów. Kolejnym pasmem górskim w południowej części Alaski (na granicy z Kanadą) są Góry Św. Eliasza (St. Elias Mountains), których wierzchołki przekraczają 5000 m n.p.m.

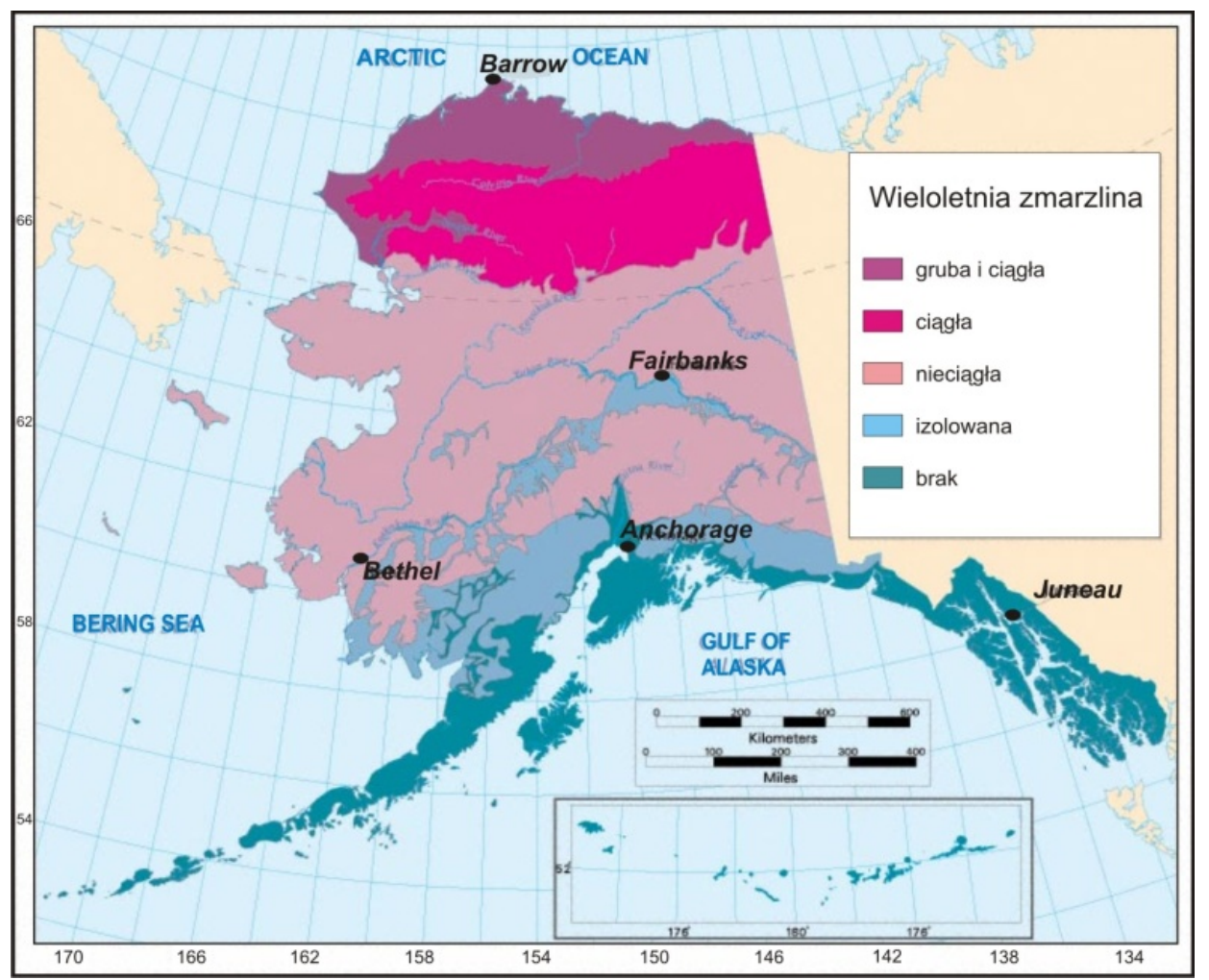

Rys. 2. Zasięg wieloletniej zmarzliny na obszarze Alaski Źródło: opracowanie na podstawie http://www.akhistorycourse.org/ articles/article.php?artID=123

Fig. 2. Coverage of permafrost in the area of Alaska Source: http://www.akhistorycourse. org/articles/article.php?artID=123 


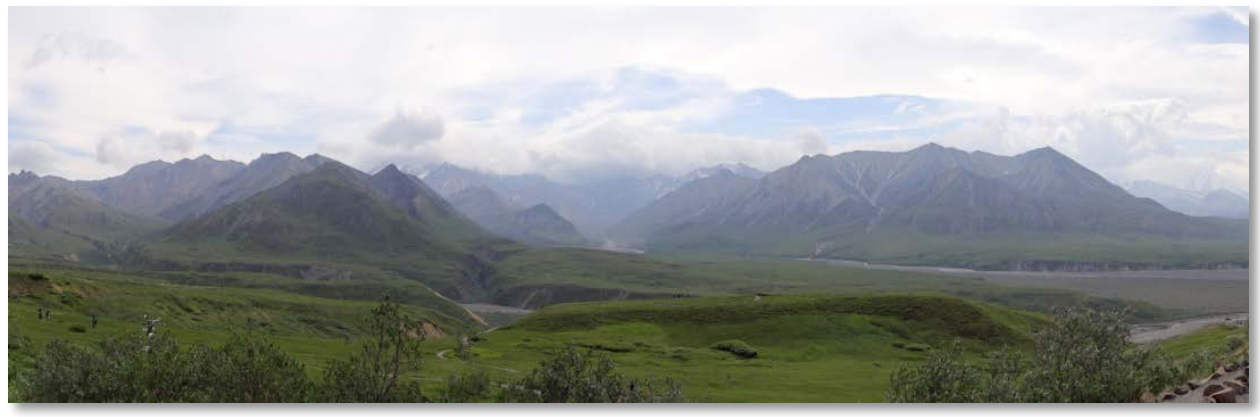

Fot. 1. Góry Alaska - Park Narodowy Denali (fot. E. Papińska, 2013)

Photo 1. Alaska Mountains - Denali National Park (photo: E. Papińska, 2013)

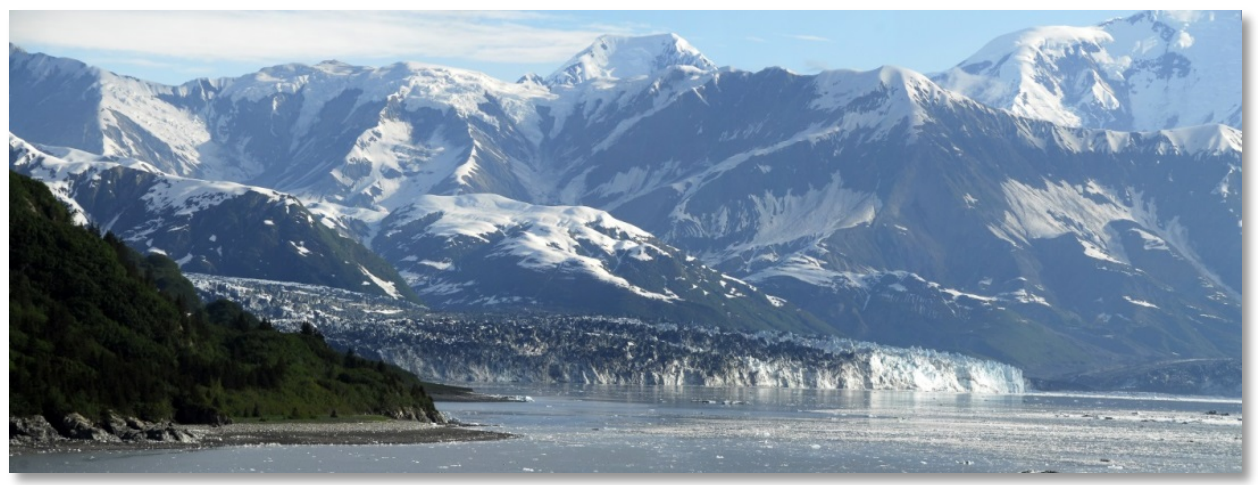

Fot. 2. Góry Nadbrzeżne - Park Narodowy Glacier Bay (fot. E. Papińska, 2013)

Photo 2. Coast Mountains - Glacier Bay National Park (photo: E. Papińska, 2013)

Wyżyny i niewielkie pasma górskie rozciągają się na północ od gór Alaska. Wznoszą się one średnio na około 1000 m n.p.m. Najwyższe wzniesienia znajdują się w obrębie wyżyny Jukon-Tanana, jest to Mt Harper osiągający 1986 m n.p.m. (Jelonek, Soja, red. 1996). W centrum Alaski występują rozległe niziny - Nizina Środkowego Jukonu (fot. 3) o powierzchni ponad 24 tys. km², Nizina Dolnego Jukonu i Kuskokwim oraz rozległe doliny systemów rzecznych: Koyukuk, Porcupine, czy Tanana. Dalej w kierunku północnym znajduje się rozległe pasmo Gór Brooksa, które osiąga wysokość ponad 2000 m n.p.m. (Mt. Michelson 2816 m n.p.m.), a dalej Arktyczna Równina Nadbrzeżna. Jej bagnistą powierzchnię urozmaicają tysiące jezior oraz pagórki pingo. 


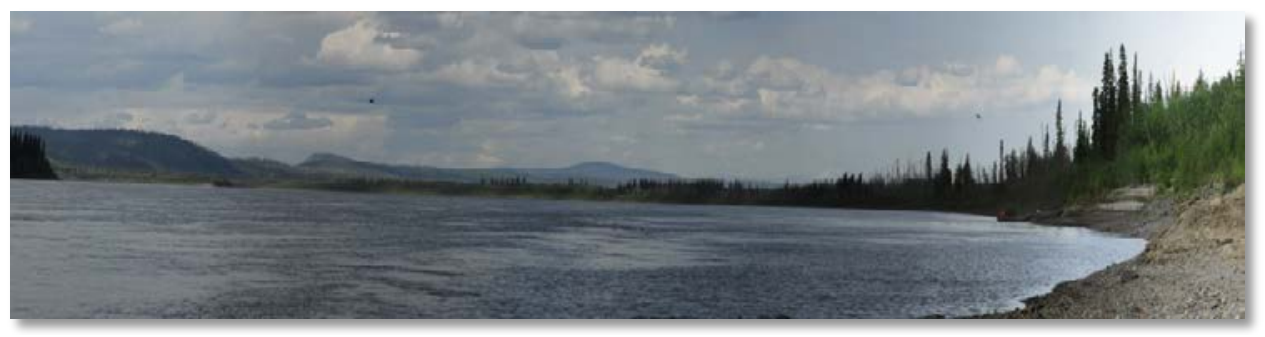

Fot. 3. Nizina Środkowego Jukonu (fot. E. Papińska, 2013)

Photo 3. Intermontane Plateaus - Middle Yukon Lowland (photo: E. Papińska, 2013)

Celem pracy jest przybliżenie walorów przyrodniczych Alaski ukazanej, jako obszar recepcji turystycznej, czyli takiego miejsca, do którego kieruje się ruch turystyczny (Dziedzic 1998). Uznano, że walory przyrodnicze w zasadniczy sposób wpływają na rozwój ruchu turystycznego na Alasce. Przyjęto założenie, że wielkość ruchu turystycznego może odzwierciedlać atrakcyjność poszczególnych obszarów. Ponieważ ruch turystyczny monitorowany jest w jednolity sposób na obszarach parków narodowych, w artykule wykorzystano dane statystyczne gromadzone przez służby parków narodowych, udostępniane przez Zarząd Parków Narodowych USA w internetowym serwisie informacyjnym (https://irma.nps.gov). Wyniki analiz danych statystycznych zostały poddane subiektywnej autorskiej weryfikacji, której dokonano na podstawie bezpośrednich obserwacji terenowych.

\section{RUCH TURYSTYCZNY NA ALASCE}

Zaprezentowane warunki środowiska przyrodniczego nie sprzyjają zasiedlaniu Alaski. Mało przekształcone i bardzo zróżnicowane ekosystemy tego regionu, stanowią ogromną atrakcję turystyczną i rokrocznie przyciągają coraz większe rzesze turystów (rys. 3). Rekordowy pod względem wielkości ruchu turystycznego był rok 2007, w którym na Alaskę tylko w okresie letnim przybyło 1 714,1 tys. turystów (Alaska Visitor Statistic Program VI, Interim Visitor Volume Report, Summer 2012). 


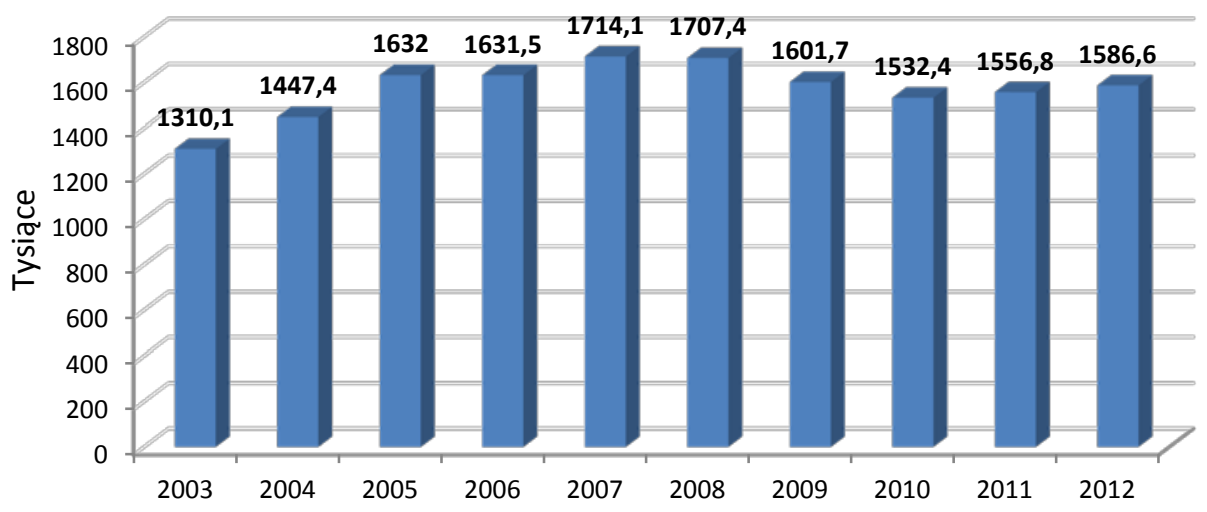

Rys. 3. Liczba turystów (w tys.) w okresie letnim (V-IX) odwiedzających Alaskę w latach 2003-2012

Źródło: Alaska Visitor Statistic Program VI, Interim Visitor Volume Report, Summer 2012

Fig. 3. The number of tourists during the summer (May-September) visiting Alaska in 2003-2012

Source: Alaska Visitor Statistic Program VI, Interim Visitor Volume Report, Summer 2012

Znamienny jest fakt, w jaki sposób turyści przybywają na Alaskę, bądź ją opuszczają, a jakimi środkami transportu przemieszczają się i zwiedzają wybrane rejony Alaski. Porównanie danych zamieszczonych na rys. 4 i 5 ukazuje pewną różnicę dotyczącą większego udziału turystów w rejsach morskich, podczas których wjeżdżają na obszar stanu Alaska. Zazwyczaj, po zakończonym rejsie turyści opuszczają Alaskę samolotem (stąd 10\% wzrost udzialu tego środka transportu, którym turyści opuszczają stan) lub też biorą udział w rejsie powrotnym (fot. 4,5 ).

Tak duży udział turystów korzystających z drogi wodnej i powierznej, a nie lądowej, związany jest przede wszystkim z brakiem infrastruktury drogowej. Niewiele osób zdaje sobie sprawę, że nawet do stolicy Alaski - Juneau - nie można się dostać drogą lądową, lecz tylko drogą morską lub powietrzną. Jedyną drogę, która przecina Alaskę z północy na południe zbudowano w 1974 r. na potrzeby budowy ropociągu transportującego ropę naftową z Deadhorse do Valdez, gdzie znajduje się port dla tankowców. Nie jest to jednak droga, którą na całej długości turyści mogą przemieszczać się samochodem osobowym lub kamperem (RVcar), gdyż w niewielkiej odleglości na północ od Fairbanks jest ona pozbawiona nawierzchni asfaltowej (fot. 6). Niestety, panujące tu warunki atmosferyczne i wieloletnia zmarzlina powodują jej niszczenie. 


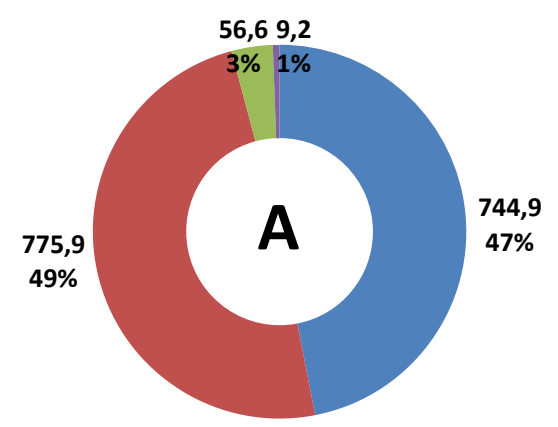

samolot $\square$ rejs $\square$ autostrada $\square$ prom

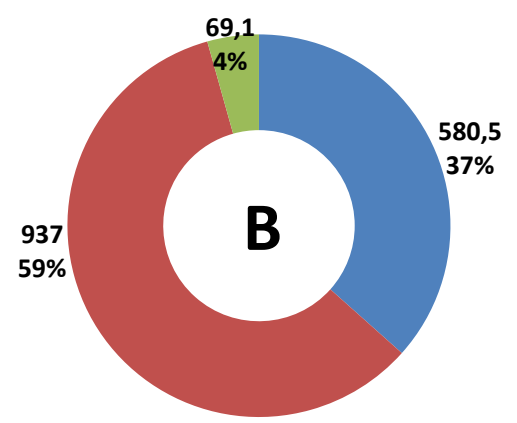

samolot $\square$ rejs autostrada/prom

Rys. 4. Liczba turystów (w tys. i \%) odwiedzających Alaskę w okresie letnim w 2012r::

A - według rodzaju środka transportu, którym wyjeżdżali z terytorium Alaski;

B - według rodzaju transportu, którym wjeżdżali na Alaskę

Źródło: Alaska Visitor Statistic Program VI, Interim Visitor Volume Report,

Summer 2012

Fig. 4. Number of tourists (in thous., and \%) visiting Alaska in the summer of 2012:

A - by type of transport, by which they were leaving the territory of Alaska,

B - by type of transport, by which they entered Alaska

Source: Alaska Visitor Statistic Program VI, Interim Visitor Volume Report,

Summer 2012

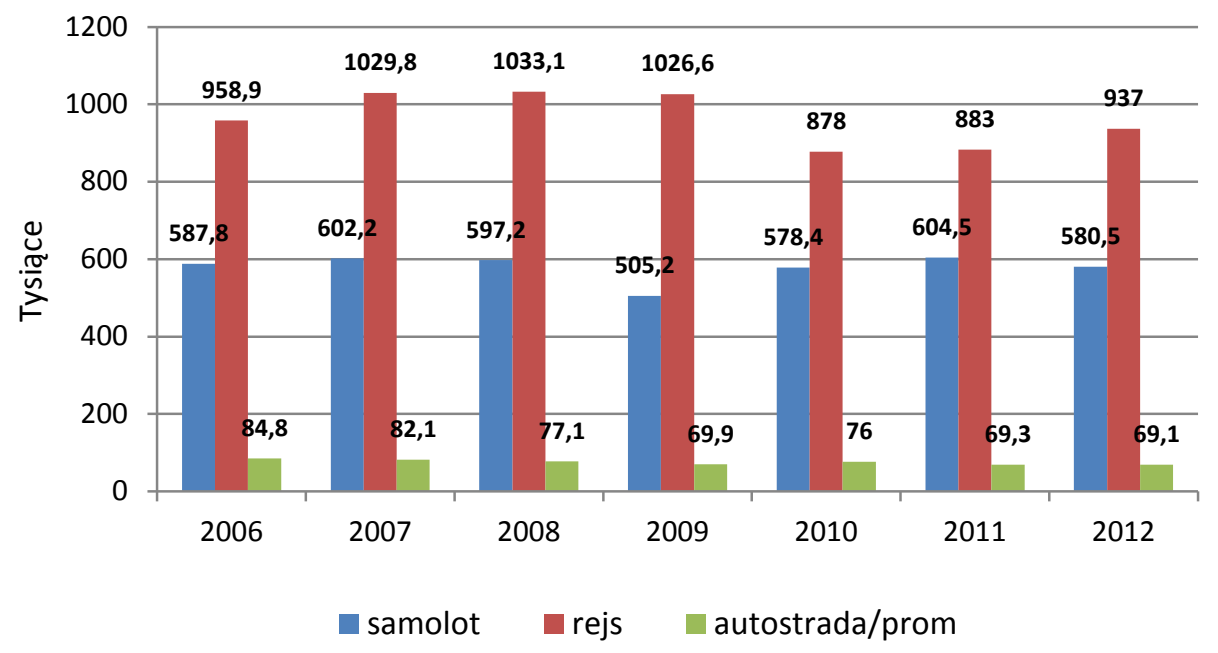

Rys. 5. Liczba turystów (w tys.) według rodzaju transportu, którym wjeżdżali na Alaskę Źródło: Alaska Visitor Statistic Program VI, Interim Visitor Volume Report,

Summer 2012

Fig. 5. Number of tourists (in thous.) by mode of transport, by which they entered Alaska

Source: Alaska Visitor Statistic Program VI, Interim Visitor Volume Report,

Summer 2012 


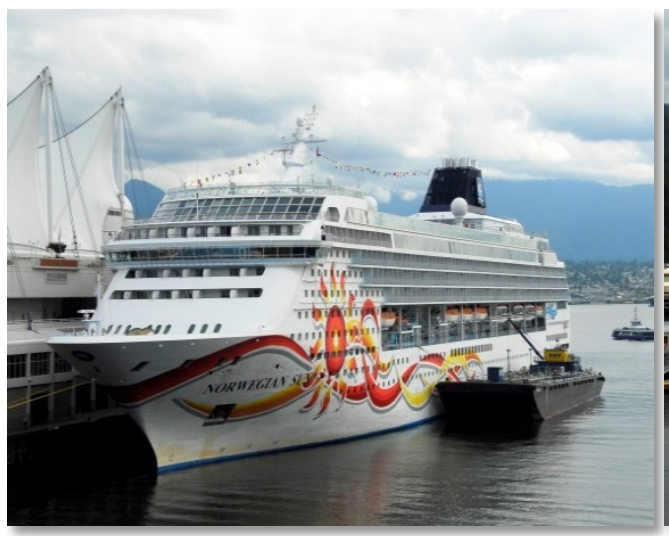

Fot. 4. Port w Vancouver w Kanadzie m.in. stąd rozpoczynają się rejsy na Alaskę. Statek Norwegian Sun bierze na pokład około 2 tys. pasażerów i 900 osób załogi (fot. E. Papińska, 2013)

Photo 4. Port of Vancouver in Canadahere begin cruises to Alaska. The ship Norwegian Sun takes on board about two thousand. passengers and $900 \mathrm{crew}$

(photo: E. Papińska, 2013)

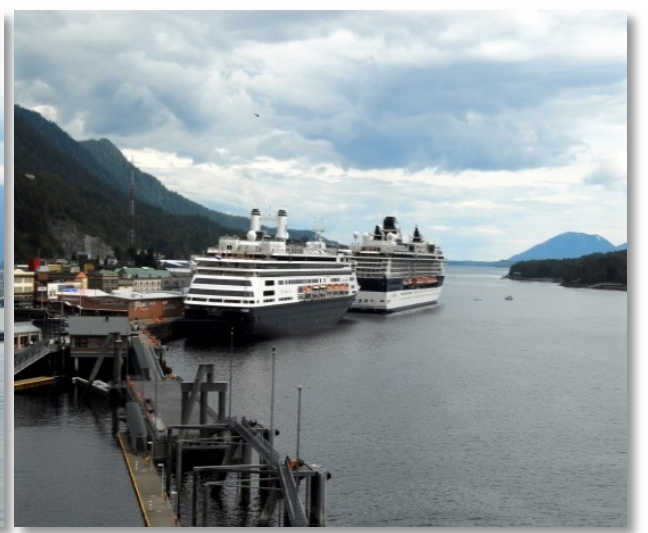

Fot. 5. Port w Juneau, stolicy Alaski, do którego zawinęły potężne statki pasażerskie, którymi podróżują turyści z całego świata (fot. E. Papińska, 2013)

Photo 5. Port of Juneau Alaska's capital, called by large passenger ships, with tourists from around the world (photo: E. Papińska, 2013)

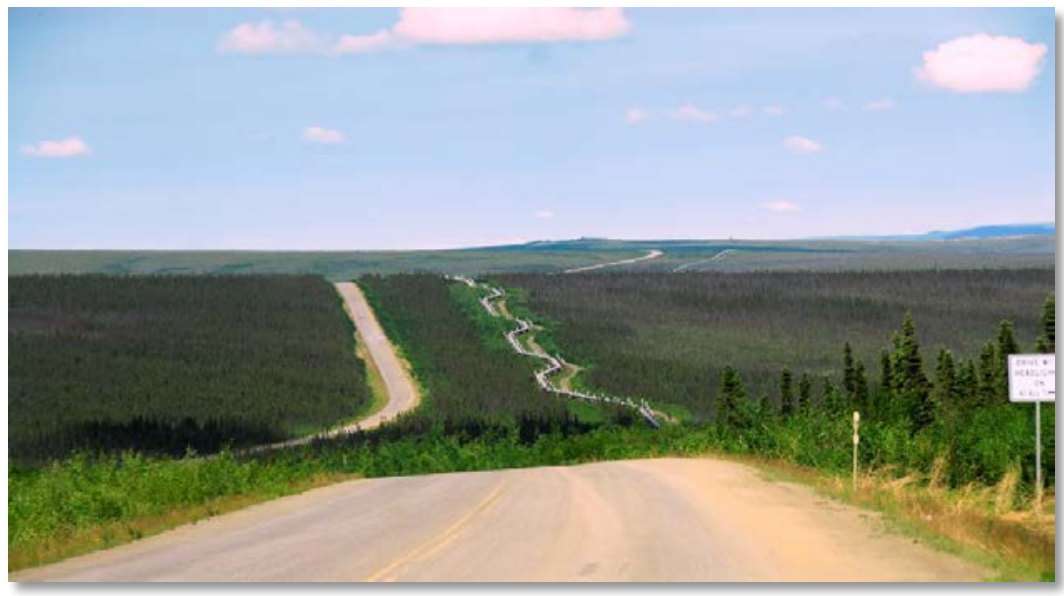

Fot. 6. Dalton Highway z biegnącym równolegle ropociągiem (fot. E. Papińska, 2013)

Photo 6. Dalton Highway runs parallel with the pipeline (photo: E. Papińska, 2013) 
Turyści przybywają na Alaskę także w porze jesienno-zimowej. Ze względu na trudne warunki pogodowe wielkość tego ruchu jest znacznie mniejsza i w okresie 2003-2013 kształtował się on na poziomie 266,8 tys. w sezonie 2011/12 (maksimum) i 237 tys. w sezonie 2009/10 (minimum). W okresie jesienno-zimowym większość turystów przyjeżdża na Alaskę drogą lotniczą (95\%), gdyż ze względu na panujące w tym czasie warunki atmosferyczne nie organizuje się rejsów w ten rejon świata (tab. 3).

Tab. 3

Liczba turystów odwiedzających Alaskę w sezonach zimowych 2011-12 i 2012-13

Number of tourists visiting Alaska in the winter seasons 2011-12 and 2012-13

\begin{tabular}{|l|c|r|c|r|}
\hline \multirow{2}{*}{$\begin{array}{c}\text { Środek transportu } \\
\text { na Alaskę }\end{array}$} & \multicolumn{2}{|c|}{ Sezon zimowy 2011-12 } & \multicolumn{2}{c|}{ Sezon zimowy 2012-13 } \\
\cline { 2 - 5 } & $\begin{array}{c}\text { Liczba turystów } \\
\text { (w tys.) }\end{array}$ & $\%$ & $\begin{array}{c}\text { Liczba turystów } \\
\text { (w tys.) }\end{array}$ & $\%$ \\
\hline Samolot & 255,3 & 95,69 & 252,1 & 95,82 \\
\hline Autostrada & 10,0 & 3,75 & 9,3 & 3,53 \\
\hline Prom & 1,5 & 0,56 & 1,7 & 0,65 \\
\hline Razem & 266,8 & 100,00 & 263,1 & 100,00 \\
\hline
\end{tabular}

Źródło: Alaska Visitor Statistic Program VI, Interim Visitor Volume Report, Fall/Winter 2012-13.

Source: Alaska Visitor Statistic Program VI, Interim Visitor Volume Report, Fall/Winter 2012-13.

\section{PRZYRodNiCZE WALORY TURYSTYCZNE AlASKi}

Warunki środowiska przyrodniczego, które wpływają na znaczne ograniczenie rozwoju osadnictwa na obszarze Alaski (stanowią wręcz barierę osadniczą), stają się dla wielu turystów ogromną atrakcją.

Walory przyrodnicze według wielu autorów traktowane są jako jeden z głównych czynników przyciągających turystów (Kowalczyk 2001), a w związku $\mathrm{z}$ tym mają one szczególnie duże znaczenie w wyborze kierunków wyjazdów turystycznych. Podkreśla się także, iż szczególne znaczenie dla rozwoju turystyki mają parki narodowe, rezerwaty przyrody $\mathrm{i}$ inne formy ochrony przyrody. T. Lijewski, B. Mikułowski i J. Wyrzykowski (2002) uważają, że walory turystyczne „stanowią specyficzne cechy i elementy środowiska naturalnego i działalności człowieka, które są przedmiotem zainteresowań turystów". Walory te dzielone są przez autorów ze względu na motywy ruchu turystycznego na: wypoczynkowe, krajoznawcze i specjalistyczne. Walory środowiska przyrodniczego znalazły się w obrębie walorów krajobrazowych. Grupa walorów krajobrazowych obejmuje 3 podgrupy: A - walory ukształtowane bez ingerencji człowieka (osobliwości flory i fauny; skałki i grupy skał; wąwozy, doliny i przełomy rzeczne; wodospady, źródła i wywierzyska; jaskinie i groty; głazy 
narzutowe i głazowiska; inne obiekty geologiczne); B - obiekty utworzone przez człowieka (parki zabytkowe; muzea i zbiory przyrodnicze; ogrody botaniczne i zoologiczne); C - inne (punkty widokowe; parki narodowe i krajobrazowe).

Trochę inne podejście do pojęcia walorów turystycznych prezentuje W. Gaworecki (2003). Określa je mianowicie jako dobra turystyczne (,dobro lub zespół dóbr danych przez naturę, historię lub wytworzonych przez człowieka, na które występuje popyt"), wśród których wydziela naturalne dobra (walory) turystyczne, dające ,turyście pełnię satysfakcji”. Do dóbr tych autor zalicza elementy:

- litosfery (rzeźba terenu, osobliwości geologiczne);

- atmosfery (jakość powietrza, pokrywa śnieżna, temperatura);

- hydrosfery (rzeki, potoki, jeziora, zbiorniki wodne, morza, źródła mineralne);

- pokrywy glebowej (pustynie);

- szaty roślinnej (lasy, osobliwości flory); łowna);

- świata zwierzęcego (ryby, ptaki, chronione gatunki fauny, zwierzyna

- krajobrazu naturalnego (konglomeraty wymienionych elementów walorów turystycznych o wysokich wartościach estetycznych).

Zagadnienie walorów przyrodniczych $\mathrm{w}$ turystyce przedstawił także K. Kożuchowski (2005). Autor zaprezentował dotychczasowy stan wiedzy i dyskusję nad wieloma podstawowymi pojęciami stosowanymi w geografii turyzmu, a szczególne miejsce $\mathrm{w}$ publikacji zajmują walory środowiska przyrodniczego. W większości definicji walorów turystycznych pojawiają się walory przyrodnicze, które zdaniem wielu autorów są niezwykle istotne dla rozwoju turystyki. Warto podkreślić fakt, iż walory turystyczne stanowią też element zasobów strukturalnych wpływających na potencjał turystyczny, który warunkuje rozwój turystyki na danym obszarze (Kaczmarek, Stasiak, Włodarczyk 2005).

Najcenniejsze pod względem przyrodniczym obszary Alaski podlegają prawnej ochronie. System ochrony przyrody na obszarze USA jest wielostopniowy i obejmuje różne formy ochrony na poziome federalnym, stanowym i lokalnym (http://en.wikipedia.org/wiki/Protected_areas_of_the_United_States). Zestawienie form ochrony przyrody na poziomie federalnym znajdujących się pod zarządem National Park Services (NPS) utworzonych na terenie Alaski zawiera tab. 4, a ich rozmieszczenie rys. 6. Łączna powierzchnia tylko tych form ochrony obejmuje około $26,5 \mathrm{mln}$ ha. Ponadto na opisywanym obszarze utworzono 123 stanowe obszary i obiekty chronione (m.in. parki stanowe), które zajmują $8,15 \mathrm{mln}$ ha. Lasy Państwowe objęte ochroną obejmują 9,5 $\mathrm{mln}$ ha. Przytaczając tylko dane odnoszące się do tych wybranych form ochrony widoczna jest skala działań zmierzających do objęcia ochroną jak największych obszarów charakteryzujących się unikatowym środowiskiem przyrodniczym. 
Tab. 4

Obszary chronione pod zarządem National Park Service i National Forest na terenie Alaski

Protected areas managed by the National Park Service and National Forest in Alaska

\begin{tabular}{|c|c|c|c|c|}
\hline Obszary chronione & $\begin{array}{l}\text { Współrzędne } \\
\text { centrum obszaru } \\
\text { chronionego }\end{array}$ & $\begin{array}{c}\text { Data } \\
\text { utworzenia }\end{array}$ & $\begin{array}{l}\text { Powierzchnia } \\
\text { (w ha) }\end{array}$ & $\begin{array}{l}\text { Liczba turystów } \\
\text { w } 2012 \text { r. }\end{array}$ \\
\hline \multicolumn{5}{|c|}{ Obszary chronione pod zarządem National Park Service } \\
\hline $\begin{array}{l}\text { Aniakchak National } \\
\text { Mounment }\end{array}$ & $\begin{array}{r}56^{\circ} 50^{\prime} 00^{\prime \prime} \mathrm{N} \\
158^{\circ} 15^{\prime} 02^{\prime \prime} \mathrm{W} \\
\end{array}$ & 01.12 .1978 & 243335 & 19 \\
\hline $\begin{array}{l}\text { Bering Land Bridge } \\
\text { National Preserve }\end{array}$ & $\begin{array}{r}65^{\circ} 50 \prime \mathrm{N} \\
164^{\circ} 10^{\prime} \mathrm{W}\end{array}$ & 01.12 .1978 & 1091595 & 2642 \\
\hline $\begin{array}{l}\text { Cape Krusenstern } \\
\text { National Monument }\end{array}$ & $\begin{array}{r}67^{\circ} 20^{\prime} 0^{\prime \prime} \mathrm{N} \\
163^{\circ} 35^{\prime} 0^{\prime \prime} \mathrm{W} \\
\end{array}$ & 02.12 .1980 & 262674 & 24950 \\
\hline Denali National Park & $\begin{array}{r}63^{\circ} 20^{\prime} 0^{\prime \prime} \mathrm{N} \\
150^{\circ} 30^{\prime} 0^{\prime \prime} \mathrm{W} \\
\end{array}$ & 26.02.1917 & 2450000 & 392844 \\
\hline $\begin{array}{l}\text { Gates of the Arctic } \\
\text { National Park }\end{array}$ & $\begin{array}{r}67^{\circ} 47^{\prime} 0^{\prime \prime} \mathrm{N} \\
153^{\circ} 18^{\prime} 0^{\prime \prime} \mathrm{W}\end{array}$ & 02.12 .1980 & 3428701,5 & 10899 \\
\hline $\begin{array}{l}\text { Glacier Bay National } \\
\text { Park }\end{array}$ & $\begin{array}{r}58^{\circ} 30^{\prime} \mathrm{N} \\
137^{\circ} 00^{\prime} \mathrm{W}\end{array}$ & 02.12 .1980 & 1304457 & 454337 \\
\hline Katmai National Park & $\begin{array}{r}58^{\circ} 30^{\prime} 00^{\prime \prime} \mathrm{N} \\
155^{\circ} 00^{\prime} 00^{\prime \prime} \mathrm{W} \\
\end{array}$ & 02.12 .1980 & 1656409,5 & 39818 \\
\hline $\begin{array}{l}\text { Kenai Fjords National } \\
\text { Park }\end{array}$ & $\begin{array}{r}59^{\circ} 55^{\prime} 04^{\prime \prime} \mathrm{N} \\
149^{\circ} 59^{\prime} 15^{\prime \prime} \mathrm{W} \\
\end{array}$ & 02.12 .1980 & 271133 & 281279 \\
\hline $\begin{array}{l}\text { Klondike Gold Rush } \\
\text { National Historical Park }\end{array}$ & $\begin{array}{r}59^{\circ} 27^{\prime} 23^{\prime \prime} \mathrm{N} \\
135^{\circ} 18^{\prime} 43^{\prime \prime} \mathrm{W} \\
\end{array}$ & 30.06.1976 & 5259 & 854250 \\
\hline $\begin{array}{l}\text { Kobuk Valley National } \\
\text { Park }\end{array}$ & $\begin{array}{r}67^{\circ} 33^{\prime} 0^{\prime \prime} \mathrm{N} \\
159^{\circ} 17^{\prime} 0^{\prime \prime} \mathrm{W} \\
\end{array}$ & 02.12 .1980 & 708490 & 29550 \\
\hline Lake Clark National Park & $\begin{array}{r}60^{\circ} 58^{\prime} 00^{\prime \prime} \mathrm{N} \\
153^{\circ} 25^{\prime} 00^{\prime \prime} \mathrm{W} \\
\end{array}$ & 02.12 .1980 & 1630889 & 11639 \\
\hline Noatak National Preserve & $\begin{array}{r}68^{\circ} 00^{\prime} \mathrm{N} \\
159^{\circ} 30^{\prime} \mathrm{W}\end{array}$ & 01.12. 1978 & 2658746 & 31000 \\
\hline $\begin{array}{l}\text { Sitka National Historical } \\
\text { Park }\end{array}$ & $\begin{array}{r}57^{\circ} 02^{\prime} 49^{\prime \prime} \mathrm{N} \\
135^{\circ} 18^{\prime} 50^{\prime \prime} \mathrm{W} \\
\end{array}$ & 18.10.1972 & 45 & 195157 \\
\hline $\begin{array}{l}\text { Wrangell-St. Elias } \\
\text { National Park }\end{array}$ & $\begin{array}{r}61^{\circ} 00^{\prime} \mathrm{N} \\
142^{\circ} 00^{\prime} \mathrm{W}\end{array}$ & \begin{tabular}{|c|}
$02.12 .1980(\mathrm{NP})$ \\
$01.12 .1978(\mathrm{NM})$
\end{tabular} & 5332057 & 87158 \\
\hline $\begin{array}{l}\text { Yukon-Charley Rivers } \\
\text { National Preserve }\end{array}$ & $\begin{array}{r}65^{\circ} 00^{\prime} \mathrm{N} \\
143^{\circ} 30^{\prime} \mathrm{W} \\
\end{array}$ & 02.12 .1978 & 1022038 & 1393 \\
\hline \multicolumn{5}{|c|}{ Obszary chronione pod zarządem National Forest } \\
\hline Tongass & $\begin{array}{r}56^{\circ} 48^{\prime} \mathrm{N} \\
133^{\circ} 54^{\prime} \mathrm{W}\end{array}$ & 10.09.1907 & 6704360 & b.d. \\
\hline Chugach & $\begin{array}{r}60^{\circ} 23^{\prime} \mathrm{N} \\
147^{\circ} 23^{\prime} \mathrm{W} \\
\end{array}$ & 23.07.1907 & 2795800 & b.d. \\
\hline
\end{tabular}

Źródło: https://irma.nps.gov/Stats/Reports/Park; dostęp 03.12.2013.

Source: https://irma.nps.gov/Stats/Reports/Park; access 03.12.2013. 


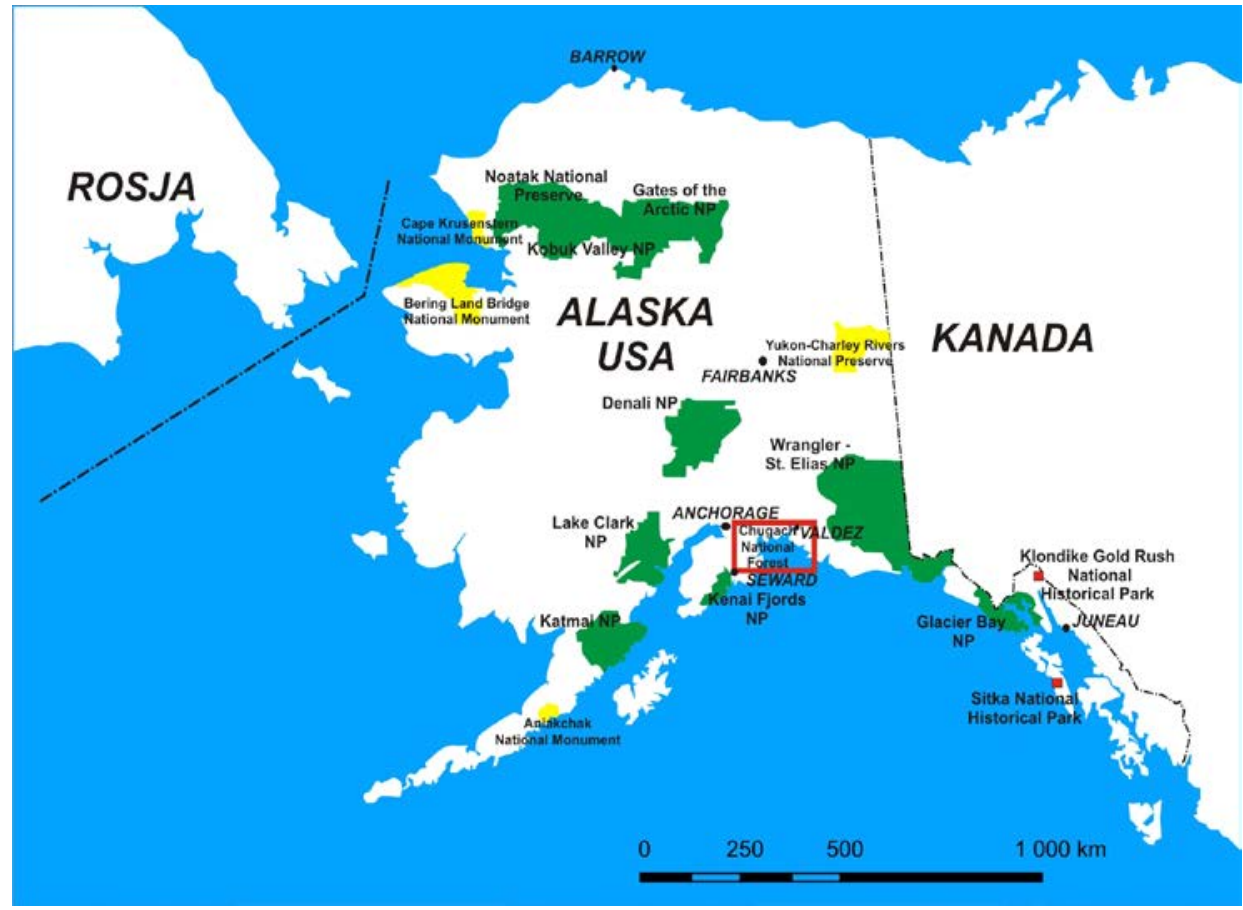

Rys. 6. Parki narodowe Alaski

Źródło: earn.reynolds.edu/jmbarnes/stu21/DreamWeaver

Folder/smithersm/parks/index.htm; dostęp 04.12.2013

Fig. 6. National Parks of Alaska

Source: earn.reynolds.edu/jmbarnes/stu21/DreamWeaver

Folder/smithersm/parks/index.htm; access 04.12.2013

\subsection{CHARAKTERYSTYKA WYBRANYCH OBSZARÓW CHRONIONYCH}

Park Narodowy Glacier Bay został utworzony w 1980 r., w miejsce istniejącego od 1925 r. pomnika przyrody. Park położony jest w południowo-wschodniej Alasce i zajmuje powierzchnię ponad 13 tys. $\mathrm{km}^{2}$ (rys. 6). Celem ochrony jest zachowanie bardzo różnorodnych ekosystemów morskich i lądowych, w obrębie których zachodzą procesy sukcesji ekologicznej następujących w wyniku postępującego zanikania lodowców. Krajobraz tego parku tworzą wysokie góry Fairweather, będące przedłużeniem systemu Gór Św. Eliasza, osiągające ponad $4500 \mathrm{~m}$ n.p.m. (Mount Fairweather $4669 \mathrm{~m}$ n.p.m.). Powierzchnie szczytowe gór i znaczna część dolin pokryta jest lodem, który wielkimi jęzorami schodzi do wód Zatoki Lodowcowej (Glacier Bay). Tutaj właśnie można oglądać niezwykle spektakularne cielenie się lodowców (fot. 7). Efektem tego procesu są mniejsze i większe góry lodowe pływające w Zatoce. 
Linia brzegowa Parku Narodowego jest niezwykle urozmaicona, podobnie jak całej Alaski. Ustępujące lodowce, które jeszcze 250 lat temu pokrywały cały obszar dzisiejszej Zatoki Lodowcowej, aż do Cieśniny Lodowej (Icy Strait), wyżłobiły wyjątkowej urody doliny. Miąższość lodu dochodziła do $1200 \mathrm{~m}$, a masa lodu rozciągała się na długości ponad $160 \mathrm{~km}$ (Bielak 2012). Ogromna siła erozyjna wielkiej masy lodu $\mathrm{i}$ wód $\mathrm{w}$ niej $\mathrm{i}$ z niej wypływających, spowodowała powstanie głębokich obniżeń, które po regresji lodowców wypełniły się wodą. Tworzą one swoisty labirynt przesmyków, cieśnin, fiordów, zatok, którego niewątpliwą perełką jest Zatoka Lodowcowa i jej otoczenie.

Współcześnie do Zatoki Lodowcowej spływa 11 lodowców (http://www. nps.gov/glba/naturescience/upload/Tidewater-and-Lakewater-Glaciers.jpg), np.: Margerie Glacier (fot. 8), Grand Pacific Glacier (fot. 9), Rendu Glacier, Carroll Glacier, Topeka Glacier, Johns Hopkins Glacier, Glimnan Glacier, Hoonah Glacier, Lamplugh Glacier, Reid Glacier.

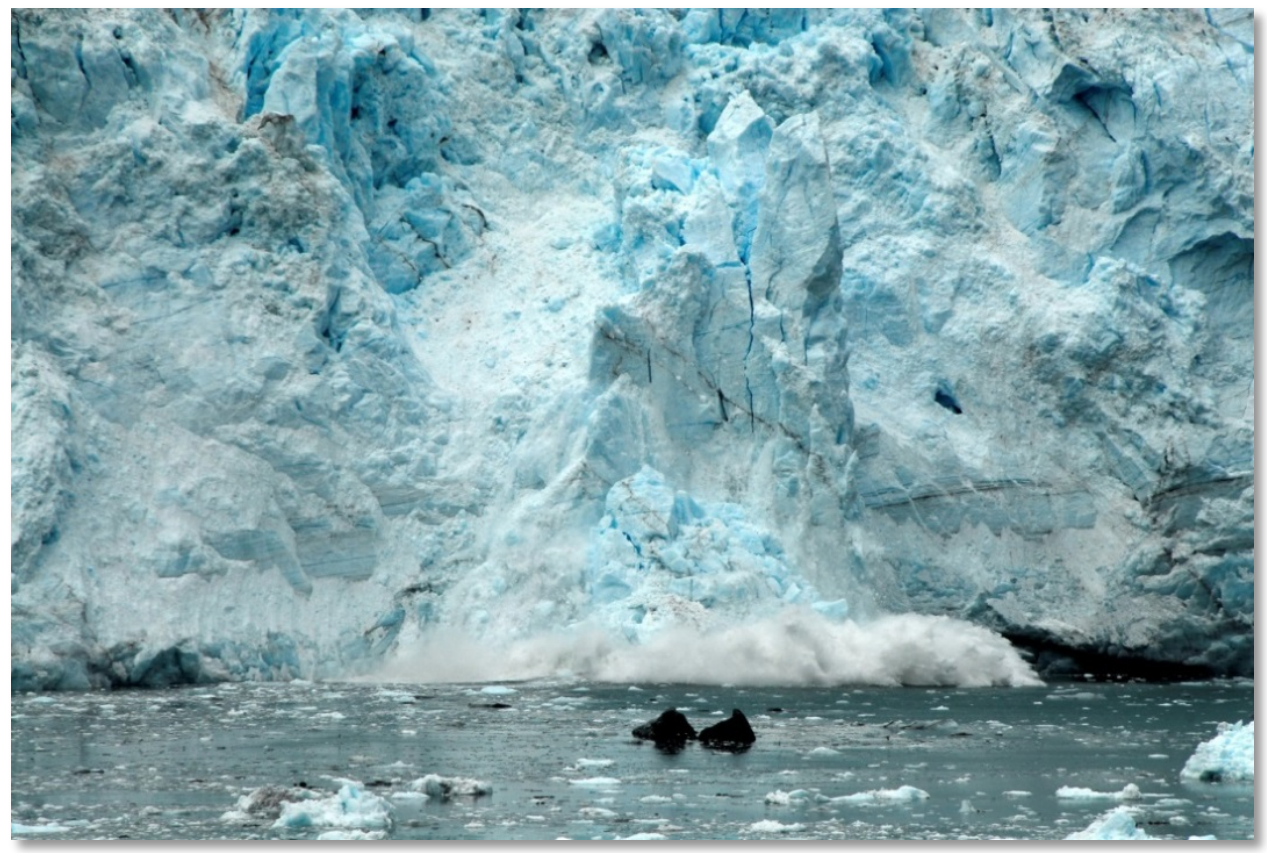

Fot. 7. Spadające wprost do wód Zatoki Lodowcowej fragmenty cielącego się lodowca (fot. E. Papińska, 2013)

Photo 7. Fragments of a disintegrating glacier falling directly into the waters of the Glacier Bay (photo: E. Papińska, 2013) 


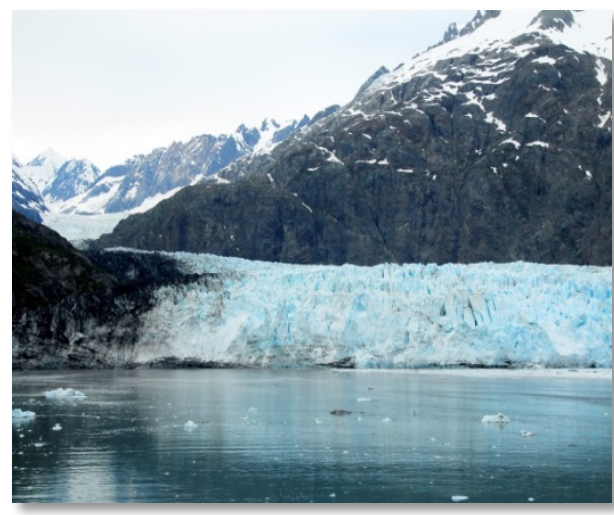

Fot. 8. Czoło lodowca Margerie

(fot. E. Papińska, 2013)

Photo 8. Margerie Glacier front

(photo: E. Papińska, 2013)

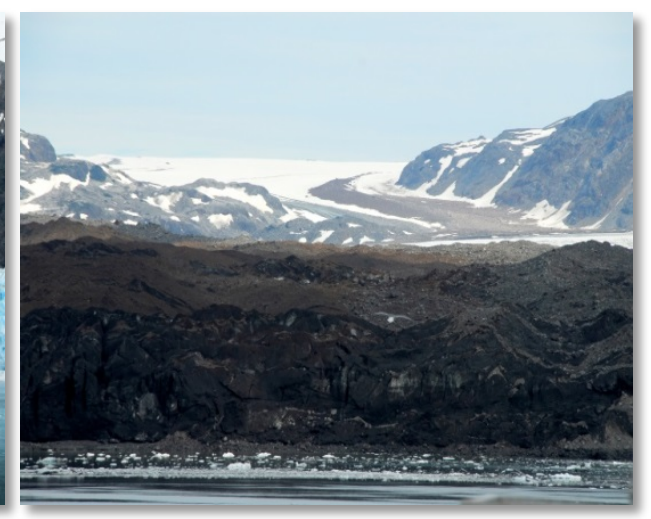

Fot. 9. Lodowiec Grand Pacific

o dł. 40 km (fot. E. Papińska, 2013)

Photo 9. Grand Pacific Glacier, 40-km long (photo: E. Papińska, 2013)

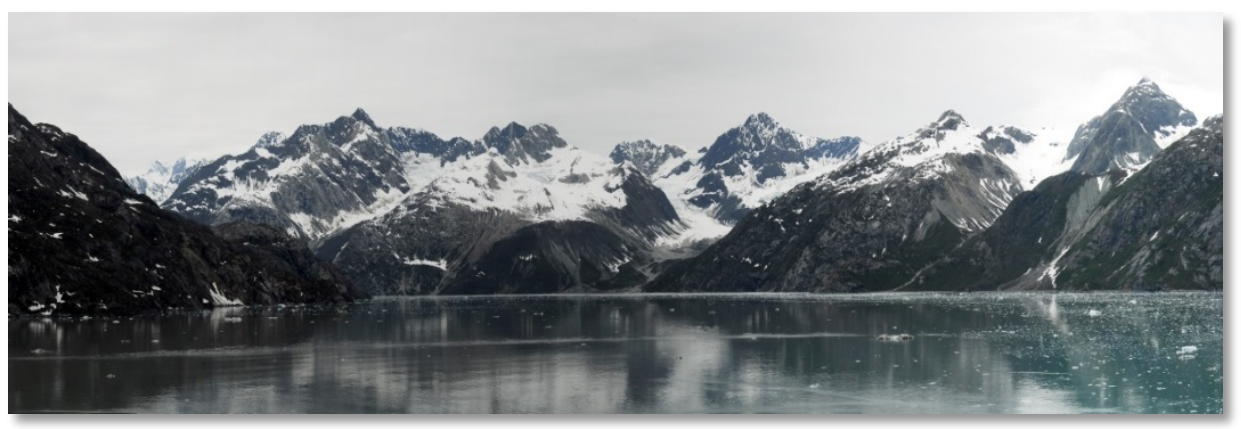

Fot. 10. Panorama Zatoki Tarr (fot. E. Papińska, 2013)

Photo 10. Panorama of the Tarr Inlet (photo: E. Papińska, 2013)

Obszar Parku Narodowego pozbawiony jest infrastruktury drogowej, co sprzyja jego izolacji od niekorzystnych wpływów związanych z masową penetracją turystyczną. Jedyna droga jaka znajduje się na opisywanym terenie wiedzie od Visitors Center w rejonie Bartleet Cove do osady Gustavus (ok. 15 km) i dalej do niewielkiego lotniska, które obsługuje lokalny ruch turystyczny. Taka sytuacja wpływa na fakt, iż ponad 80\% turystów odwiedzających Park Narodowy dostaje się na jego obszar statkami wycieczkowymi. Turyści oglądają otaczający ich krajobraz z pokładu statków, na których odbywają się także prelekcje popularno-naukowe, pokazy slajdów i filmów prowadzone przez pracowników Parku. Przy takiej formie poznawania parku, negatywne oddziaływanie na ekosystemy obszaru chronionego jest bardzo ograniczone. Oprócz statków wycieczkowych odbywających kilkudniowe rejsy, turyści dowożeni są na wycieczki także małymi statkami i promami z sąsiednich miejscowości, np. 
z Yakutat, Juneau, Haanah, Haines. Część turystów dostaje się do Parku małymi samolotami. Organizowane są także przeloty nad Parkiem, które dostarczają wiele emocji i pozwalają $\mathrm{z}$ innej perspektywy zobaczyć te niesamowite krajobrazy. W ostatnich latach park odwiedza około 450 tys. turystów rocznie (rys. 7), zaś od 1956 r., kiedy to rozpoczęto ewidencję ruchu turystycznego prawie $9,9 \mathrm{mln}$.

Oprócz krajobrazów lodowcowych i różnych form oraz procesów z nimi związanych, na obszarze Parku Narodowego Glacier Bay można obserwować sukcesję ekologiczną, która występuje na obszarach uwalnianych od lodu. Postępująca deglacjacja lodowców wpływa na zmiany zachodzące w środowisku przyrodniczym, polegające na adaptacji organizmów żywych do innych warunków i zasiedlania nowych obszarów. Zwierzęta mają na tym obszarze doskonałe warunki do rozwoju, ze względu na małą presję człowieka na tereny.

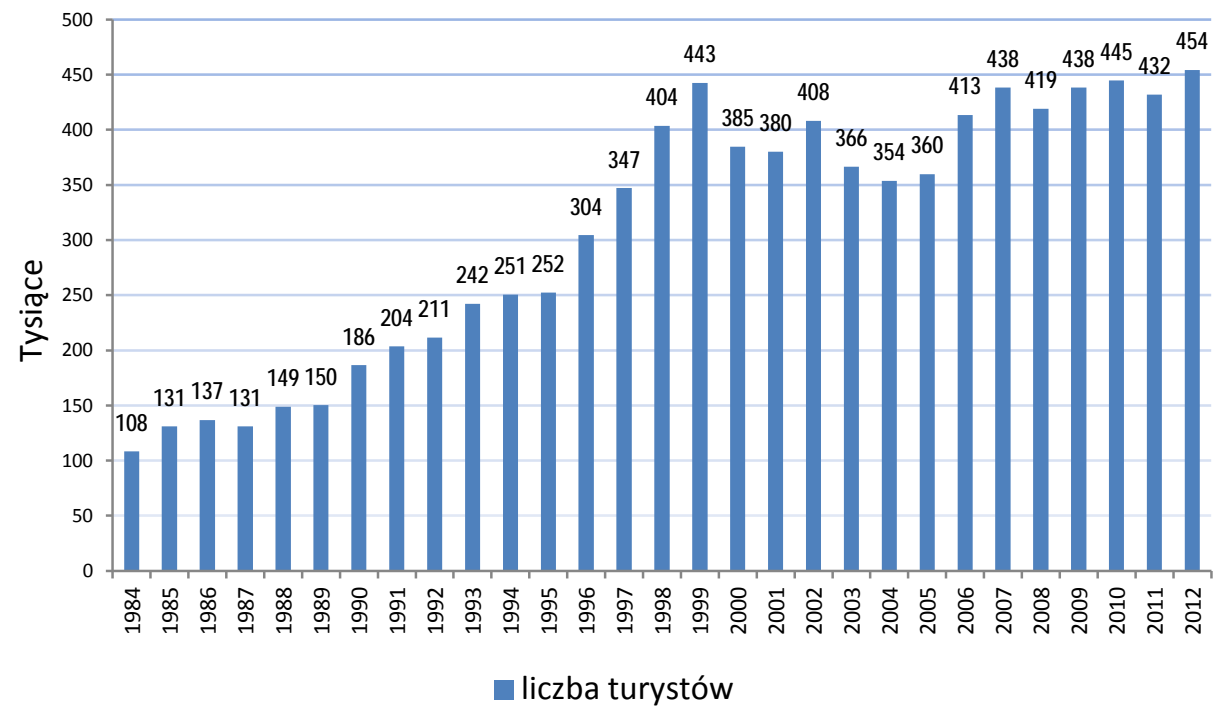

Rys. 7. Liczba turystów (w tys.) odwiedzających Park Narodowy Glacier Bay w latach 1984-2012

Źródło: https://irma.nps.gov/Stats/Reports/Park; dostęp 04.12.2013

Fig. 7. Numbers of tourists visiting Glacier Bay National Park in the years 1984-2012

Source: https://irma.nps.gov/Stats/Reports/Park; access 04.12.2013

Park Narodowy Denali został utworzony w 1917 r. pod nazwą McKinley. Początkowo obszar objęty ochroną różnił się znacznie od współczesnego, nie obejmował nawet najwyższego wzniesienia Ameryki Północnej, od którego zaczerpnięto nazwę Parku. W 1980 r. jego powierzchnia została znacznie zwiększona, tak że obecnie zajmuje $24500 \mathrm{~km}^{2}$ i nosi nazwę Denali (Denali: The story behind the scenery, 1997). 
Park położony jest w obrębie centralnej części Gór Alaska (rys. 6) i obejmuje tereny pokryte w znacznej części wiecznym śniegiem i lodowcami, z takimi kulminacjami terenu jak: Mt. McKinley (6194 m n.p.m.), Mt. Foraker (5300 m n.p.m.) i Mt. Hunter (4442 m n.p.m.). Dominantę w krajobrazie stanowi najwyższy szczyt Mt. McKinley, którego wysokość względna w stosunku do otaczających go terenów wynosi $4800 \mathrm{~m}$. W krajobrazie Parku licznie występują rozległe i głęboko wcięte doliny polodowcowe, zasilane wodami o dużej energii, spływającymi z licznych na tym obszarze lodowców (fot. 11, 12, 13). Innym walorem Parku są jeziora, np. Wonder. Niestety w okresie letnim okolice jeziora i jego podmokłe otoczenie słyną z plagi uciążliwych komarów.

Niewątpliwym walorem parku Denali jest możliwość prowadzenia obserwacji fauny oraz formacji roślinnych w nim występujących. Formacje roślinne układają się piętrowo. W obrębie dużych dolin rzecznych występują borealne lasy szpilkowe, reprezentowane głównie przez bory świerkowe (fot. 15). Wraz ze zmianami klimatycznymi na terenie Parku obserwuje się ekspansję świerka. Powyżej górnej granicy lasu, która przebiega średnio na wysokości 800-850 m n.p.m., tereny porastają trawiasto-krzewinkowe zbiorowiska tundry górskiej (fot. 16, 21, 22). Brak lasów na tej wysokości sprawia, że przestrzeń jest otwarta, co umożliwia swobodne podpatrywanie zwierząt.

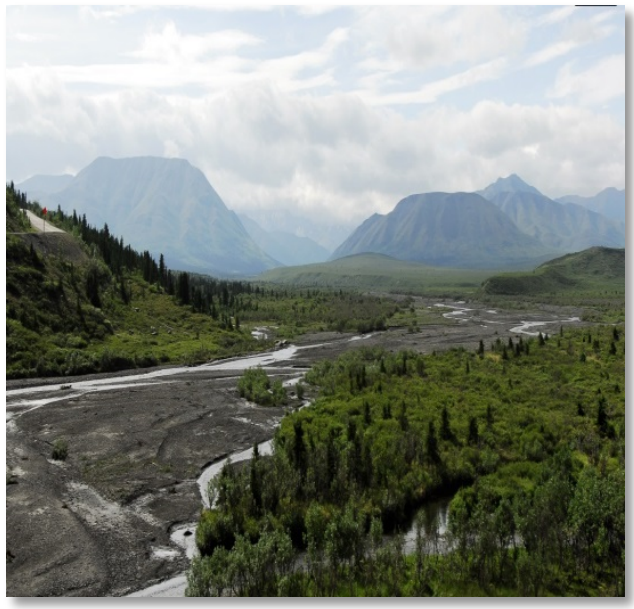

Fot. 11. Rozległa dolina z rzeką o odpływie roztokowym w Denali

(fot. E. Papińska, 2013)

Photo 11. The broad valley of the river with braided effluent in Denali (photo: E. Papińska, 2013)

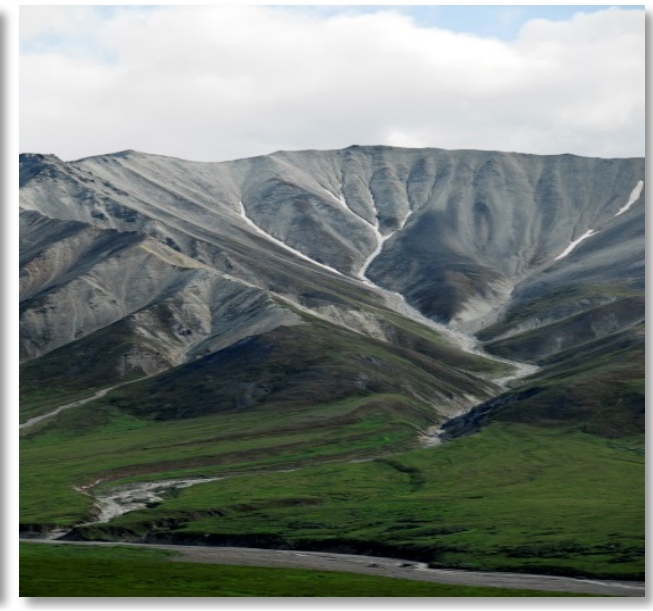

Fot. 12. Silna erozja głęboko rozcina stoki Gór Alaska (fot. E. Papińska, 2013)

Photo 12. Strong erosion cuts deep into the slopes of the Alaska Mountains (photo: E. Papińska, 2013) 


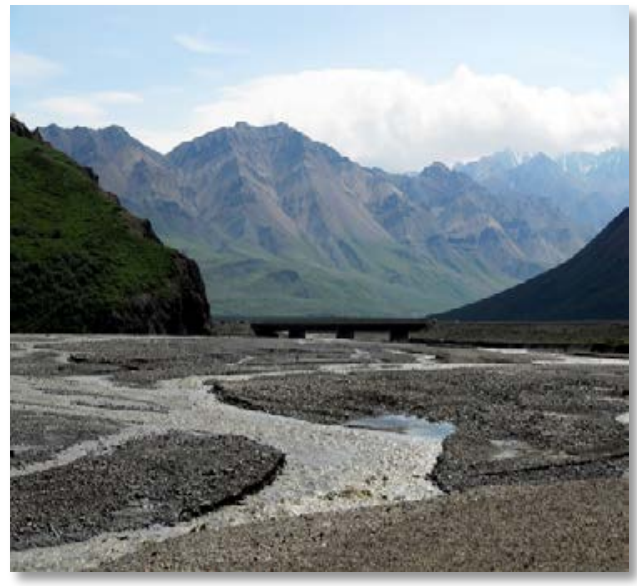

Fot. 13. Dolina z rzeką roztokową o wysokiej energii przepływu w Denali NP (fot. E. Papińska, 2013)

Photo 13. Braided river valley with high energy flow in Denali NP (photo: E. Papińska, 2013)

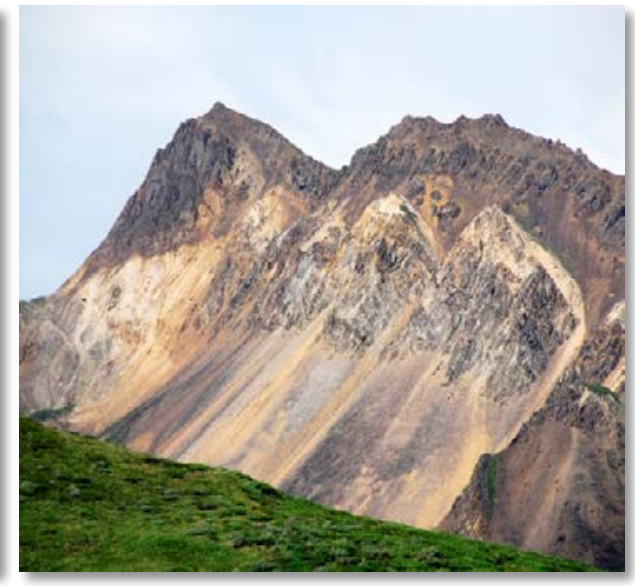

Fot. 14. Ryolity w otoczeniu Polychrome Pass (fot. E. Papińska, 2013)

Photo 14. Rhyolites surrounding the Polychrome Pass (photo: E. Papińska, 2013)

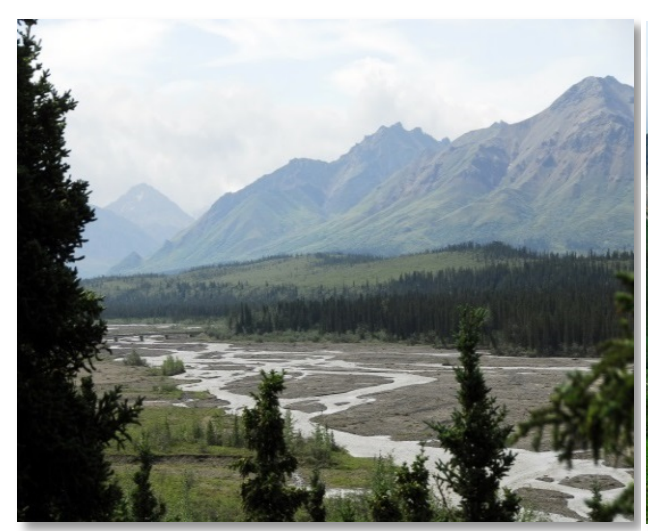

Fot. 15. Borealne lasy świerkowe w Denali (fot. E. Papińska, 2013)

Photo 15. Boreal spruce forests in Denali (photo: E. Papińska, 2013)

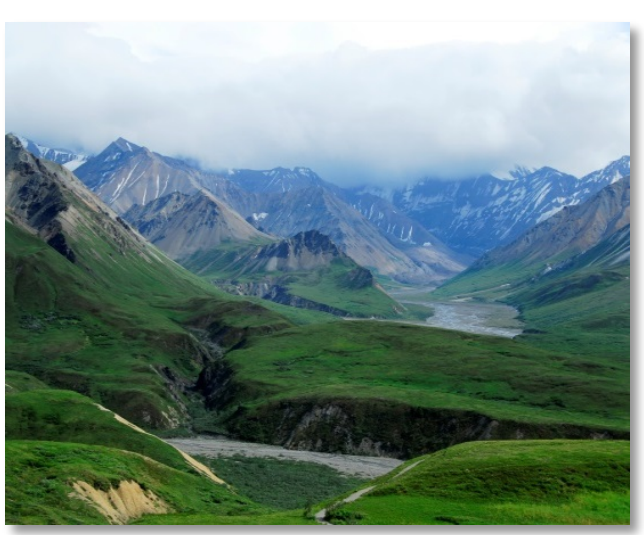

Fot. 16. Piętro tundry w Denali

(fot. E. Papińska, 2013)

Photo 16. Tundra in Denali

(photo: E. Papińska, 2013)

Wśród ssaków (39 gatunków) można zobaczyć niedźwiedzie brunatne (fot. 17, 18), łosie (fot. 19), karibu, owce Dalla, wilki, lisy polarne, zające polarne, niewielkie gryzonie (fot. 20). Występuje tu też znaczna liczba ptaków (169 gatunków), np.: borowiec czerwonobrewy, białozór, pardwa i białorzytka. W rzekach żyje ponad 140 gatunków ryb. 


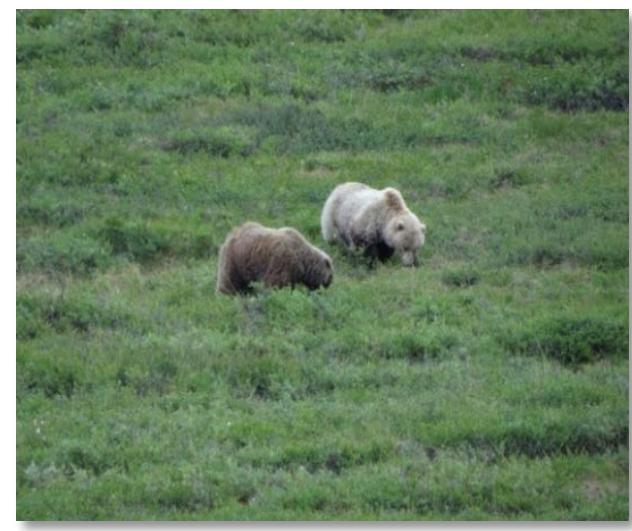

Fot. 17. Niedźwiedzie brązowe (grizzly) Ursus arctos w Denali (fot. E. Papińska, 2013)

Photo 17. Brown bears (grizzly)

Ursus arctos in Denali

(photo: E. Papińska, 2013)

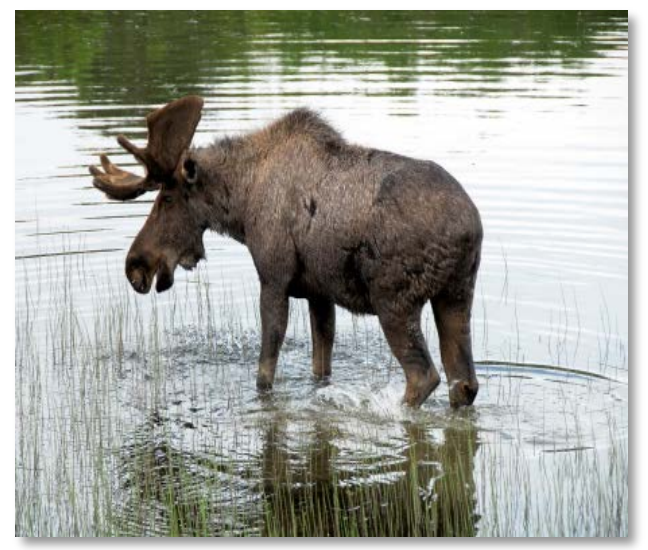

Fot. 19. Łoś alaskański Alces alces gigas (fot. E. Papińska, 2013)

Photo 19. Alaskan moose Alces alces gigas (photo: E. Papińska, 2013)

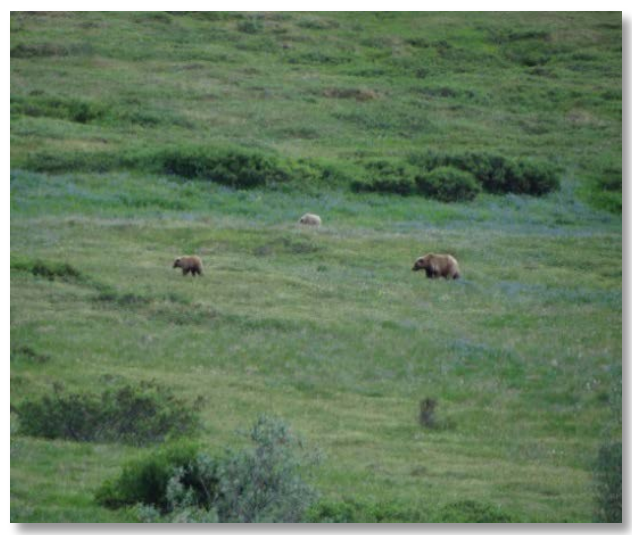

Fot. 18. Niedźwiedzica grizzly z dwójką dzieci w Denali (fot. E. Papińska, 2013)

Photo 18. Grizzly-bear with two cubs in Denali (photo: E. Papińska, 2013)

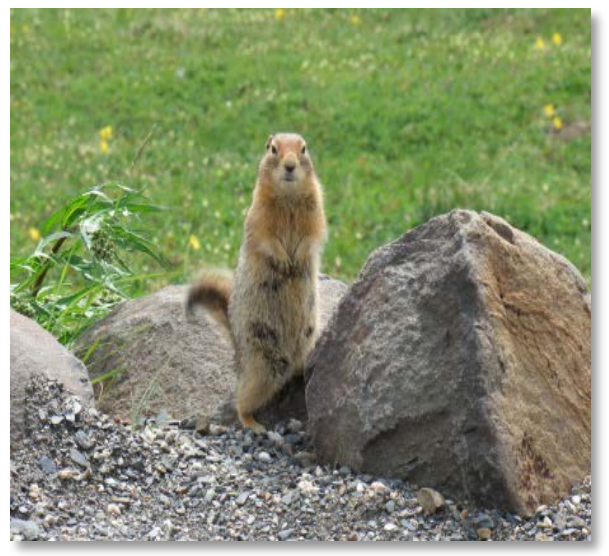

Fot. 20. Suseł północny Urocitellus parryii (fot. S. Szczurtek, 2013)

Photo 20. Arctic ground squirrel Urocitellus parryii (photo: S. Szczurtek, 2013) 


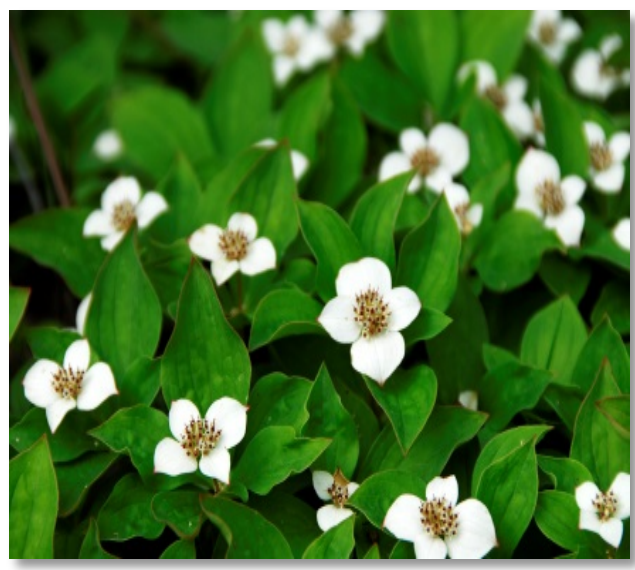

Fot. 21. Kwitnący dereń kanadyjski Cornus canadensis

(fot. E. Papińska, 2013)

Photo 21. Blooming Canadian bunchberry Cornus canadensis

(photo: E. Papińska, 2013)

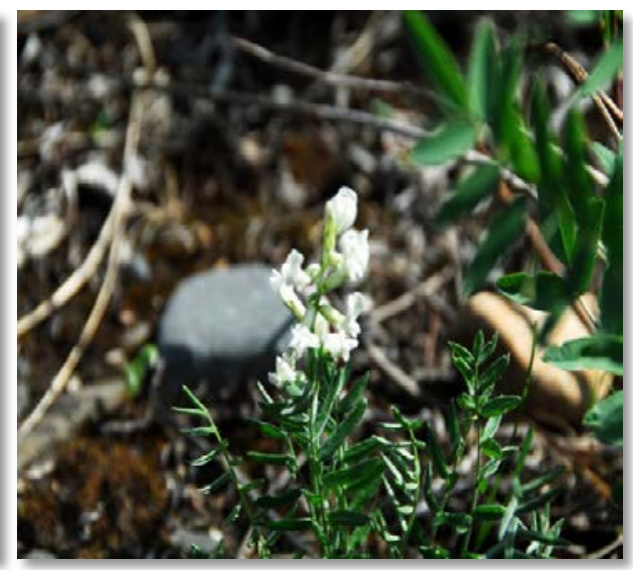

Fot. 22. Bagno grenlandzkie Ledum groenlandicum

(fot. E. Papińska, 2013)

Photo 22. Rhododendron groenlandicum Ledum groenlandicum (photo: E. Papińska, 2013)

W parku Denali liczba turystów jest limitowana, poprzez wprowadzenie zakazu poruszania się prywatnymi samochodami. Jedyna droga, która poprowadzona jest przez park, udostępniona jest dla transportu zorganizowanego przez służby Parku. Turyści, chcąc dostać się w bardziej odległe rewiry Parku, korzystają z tego transportu. Niestety dla nich, a z korzyścią dla środowiska, liczba autobusów jest ograniczona, co powoduje konieczność wcześniejszej rezerwacji miejsc. Nie ma za to większych ograniczeń dotyczących pieszego poruszania się po terenie Parku. Każdy turysta idzie na własną odpowiedzialność, nie musi poruszać się po wyznaczonych szlakach, ale musi liczyć się z ryzykiem spotkania „oko $\mathrm{w}$ oko" $\mathrm{z}$ niedźwiedziem lub też wejścia na teren podmokły lub bagienny.

Największa liczba turystów odwiedzających ten Park, 592431 osób, została zanotowana w 1988 r. (rys. 8). W 2012 r. do Parku przybyło prawie 390 tys. osób, zaś od 1922 r. (początek prowadzenia statystyk) przybyło tutaj aż 15,7 mln turystów. Dotarcie do tego miejsca wymaga trochę wysiłku, gdyż położony jest on w pewnej odległości (około $600 \mathrm{~km}$ ) od portów morskich Steward i Whittier, do których docierają wielkie statki pasażerskie. Turyści zazwyczaj kończą swój rejs i pobyt na Alasce w Anchorage, gdzie znajduje się międzynarodowy port lotniczy. Niektórzy decydują się na pozostanie kilka dni dłużej i wtedy najczęściej podążają do Parku Narodowego Denali. Najczęściej turyści korzystają z wycieczek zorganizowanych, takie oferują chociażby linie oceaniczne, jako wycieczki fakultatywne przed albo po rejsie, lub też przez licznie funkcjonujące biura turystyczne. Rzadziej turyści decydują się na wynajęcie samochodu lub kampera (RVcar) i samodzielne zwiedzanie. 


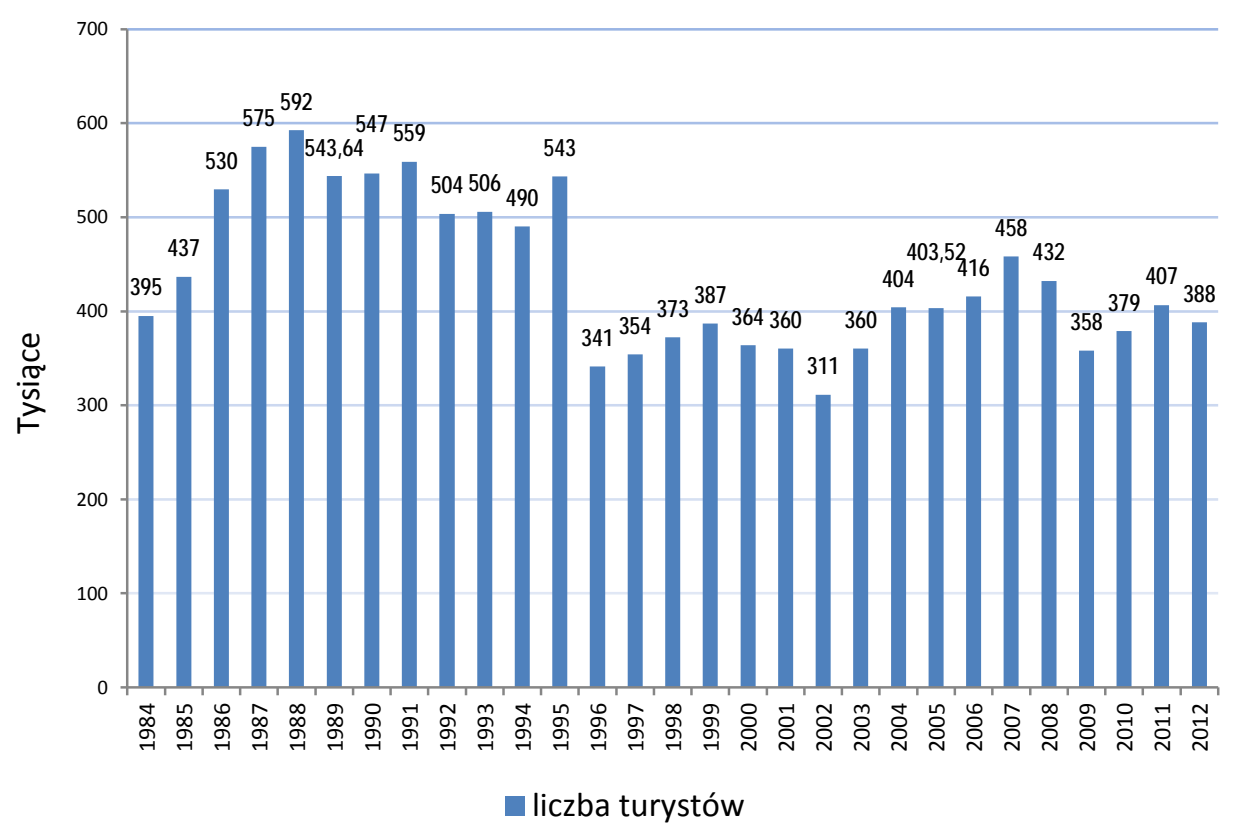

Rys. 8. Liczba turystów (w tys.) odwiedzających Park Narodowy Denali w latach 1984-2012

Źródło: https://irma.nps.gov/Stats/Reports/Park; dostęp 04.12.2013

Fig. 8. Numbers of tourists visiting the Denali National Park in the years 1984-2012 Source: https://irma.nps.gov/Stats/Reports/Park; access 04.12.2013

Park Narodowy Kenai Fjords został utworzony w 1980 r. na powierzchni $2711,33 \mathrm{~km}^{2}$. Położony jest w południowej części Alaski (rys. 6), w obrębie Półwyspu Kenai, w pobliżu miasta portowego Seward. Obszar parku obejmuje znaczną część największego pola lodowego w USA - Harding Icefield z którego spływa około 40 lodowców. Powierzchnia pola lodowego Hardinga szacowana jest na prawie $800 \mathrm{~km}^{2}$ (Rozen 1998), zaś z lodowcami spływającymi z tego pola na prawie $2850 \mathrm{~km}^{2}$. Najwyższy punkt na terenie Parku osiąga 1996 m n.p.m., zaś bliskie sąsiedztwo tak wysokich gór z linią brzegową powoduje, iż krajobraz wydaje się monumentalny. Linia brzegowa obszaru wchodzącego w skład Parku jest bardzo urozmaicona. Występuje tu ogromna liczba fiordów i dolin polodowcowych o różnych rozmiarach, które odsłaniane są spod lodowców systematycznie zmniejszających swój zasięg.

Najbardziej dostępnym lodowcem na obszarze Parku (prawdopodobnie także na całej Alasce) jest lodowiec Exit (fot. 23). Można dojechać w jego pobliże jedyną drogą w Parku odchodzącą od Seward Highway, która wiedzie do centrum informacji turystycznej. Stamtąd poprowadzone są szlaki, którymi można dojść do czoła lodowca, a także odbyć wycieczkę ścieżką wiodącą 
równolegle do jego jęzora. Po drodze ustawione są tablice informujące o historycznych zasięgach jęzora lodowcowego, co dobitnie ukazuje tempo deglacjacji lodowców na Alasce. Z punktów widokowych znajdujących się w pobliżu szlaków, widoczne jest czoło lodowca, morena czołowa, ogromne głazy narzutowe (eratyki, fot. 24), a także dolina polodowcowa, którą przemieszczał się w przeszłości jęzor lodowca, a współcześnie prowadzi ona wody spływające z jego czoła (fot. 25).

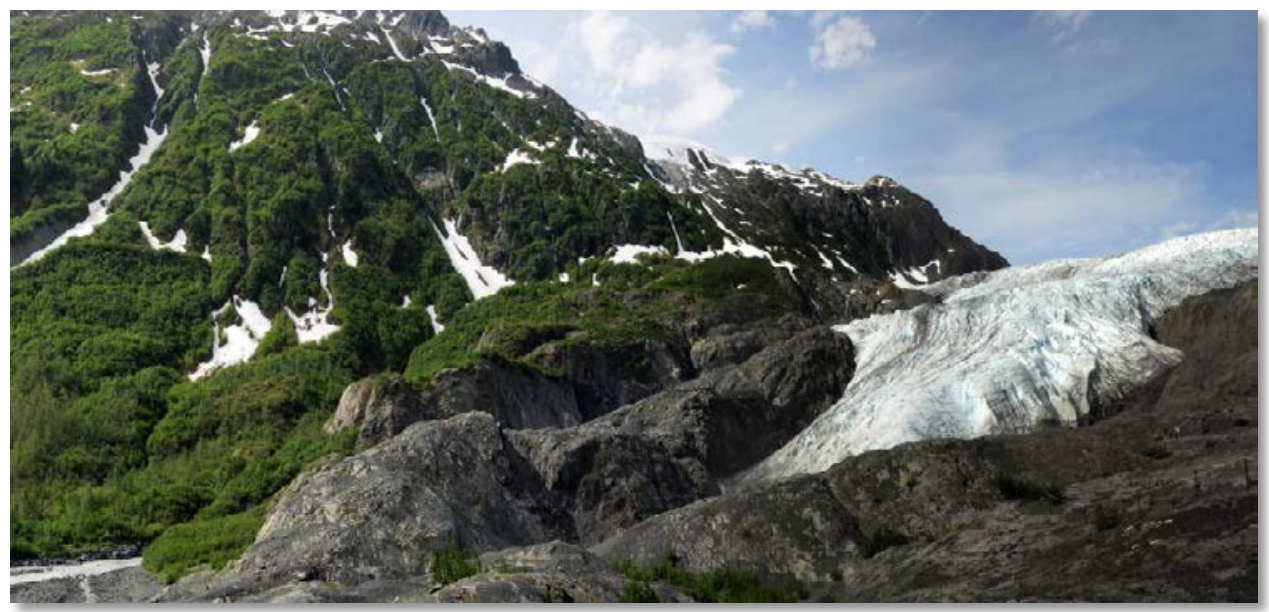

Fot. 23. Lodowiec Exit w Parku Narodowym Kenai Fjords (fot. E. Papińska, 2013)

Photo 23. Exit Glacier in the Kenai Fjords National Park (photo: E. Papińska, 2013)

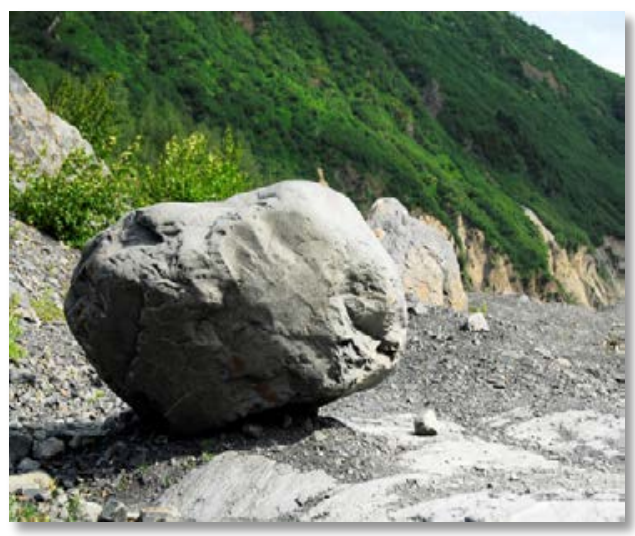

Fot. 24. Głazy narzutowe i wygłady lodowcowe w PNKF (fot. E. Papińska, 2013)

Photo 24. Boulders and glacial smoothing in KFNP (photo: E. Papińska, 2013)

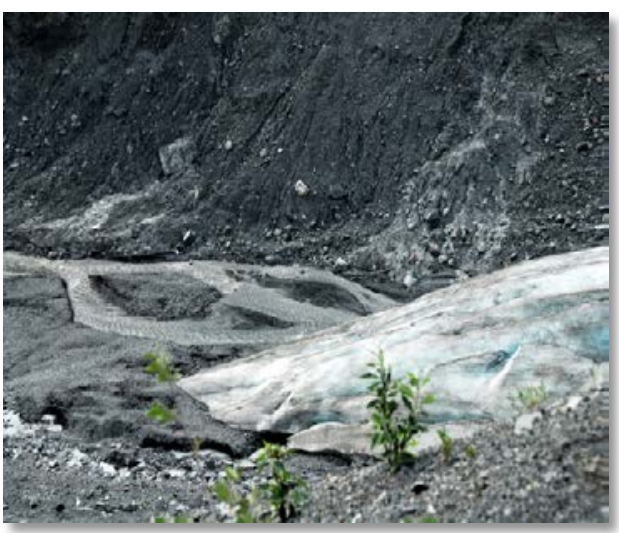

Fot. 25. Strefa marginalna lodowca Exit w PNKF (fot. E. Papińska, 2013)

Photo 25. Exit Glacier marginal zone in KFNP

(photo: E. Papińska, 2013) 


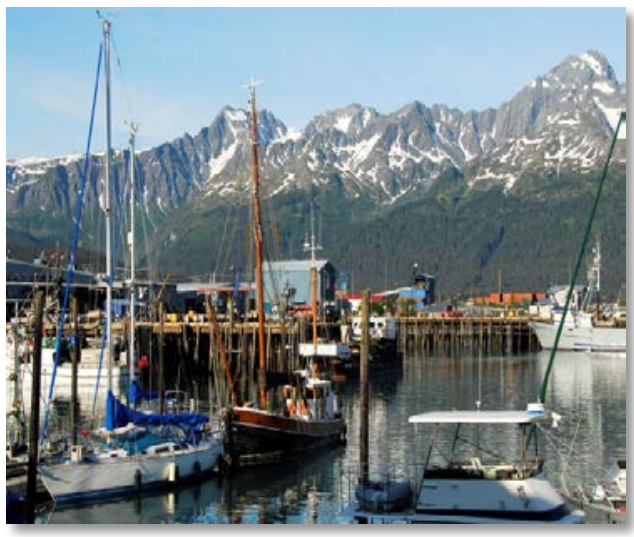

Fot. 26. Port w Seward. W tle widoczne piętra roślinne gór Kenai (fot. E. Papińska, 2013)

Photo 26. Port in Seward. Background: altitudinal vegetation belts of the Kenai Mountains

(photo: E. Papińska, 2013)

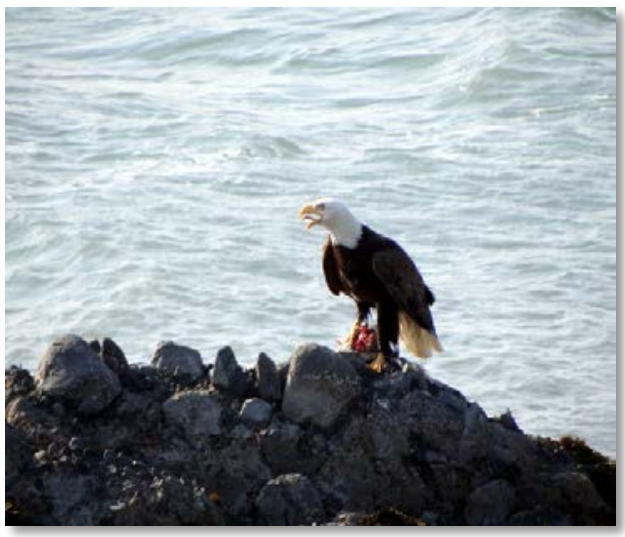

Fot. 27. Orzeł ze zdobyczą (fot. E. Papińska, 2013) Photo 27. Eagle with prey (photo: E. Papińska, 2013)

Inne rewiry Parku można zwiedzać podczas rejsów statkami wypływającymi z Seward lub kajakami (fot. 26). Przewodnicy oferują także wspinaczkę na pole lodowe Hardinga i inne lodowce. Podczas rejsów czy pieszych wędrówek można poznać dwa ekosystemy lądowe występujące na terenie Parku. Od poziomu morza do ok. 300-350 m n.p.m. rozciąga się ekosystem zatoki wybrzeża Alaski (The Gulf of Alaska Coast Ecosystem, Catton 2010). Powierzchnie te są silnie nachylone, co powoduje, że pas występowania tego ekosystemu jest bardzo wąski. Tereny te porastają lasy deszczowe umiarkowanych szerokości z dominacją świerka, przeplatane otwartymi mokradłami. Typowymi zwierzętami tego ekosystemu są niedźwiedzie brunatne i czarne, orły (fot. 27) i wydry rzeczne.

Powyżej tego ekosystemu, na obszarach wolnych od lodu występuje ekosystem Chugach-St. Elias. W ekosystemie tym warunki klimatyczne (zimny i wilgotny) umożliwiają rozwój roślinności alpejskiej na płytkich kamienistych glebach. Turzyce, trawy i niskie krzewy zapewniają pożywienie kozicom górskim, świstakom, szczekuszce amerykańskiej i pardwom. Tam, gdzie działalność egzaracyjna lodowców była silniejsza i powstały głębsze doliny z bardziej miąższymi glebami rozwiniętymi na nieskonsolidowanych osadach morenowych i aluwiach rzecznych rozwijają się lasy mieszane $\mathrm{z}$ zaroślami olchy (Catton 2010).

Ruch turystyczny w Parku kształtuje się w ostatnich latach na poziomie około 220 tys. osób w 2009 r. do prawie 350 tys. w 2011 r. (rys. 9). Od 1982 r. (początek statystyki liczby odwiedzin) do 2012 r. zarejestrowano 5,87 $\mathrm{mln}$ turystów odwiedzających ten obszar. 


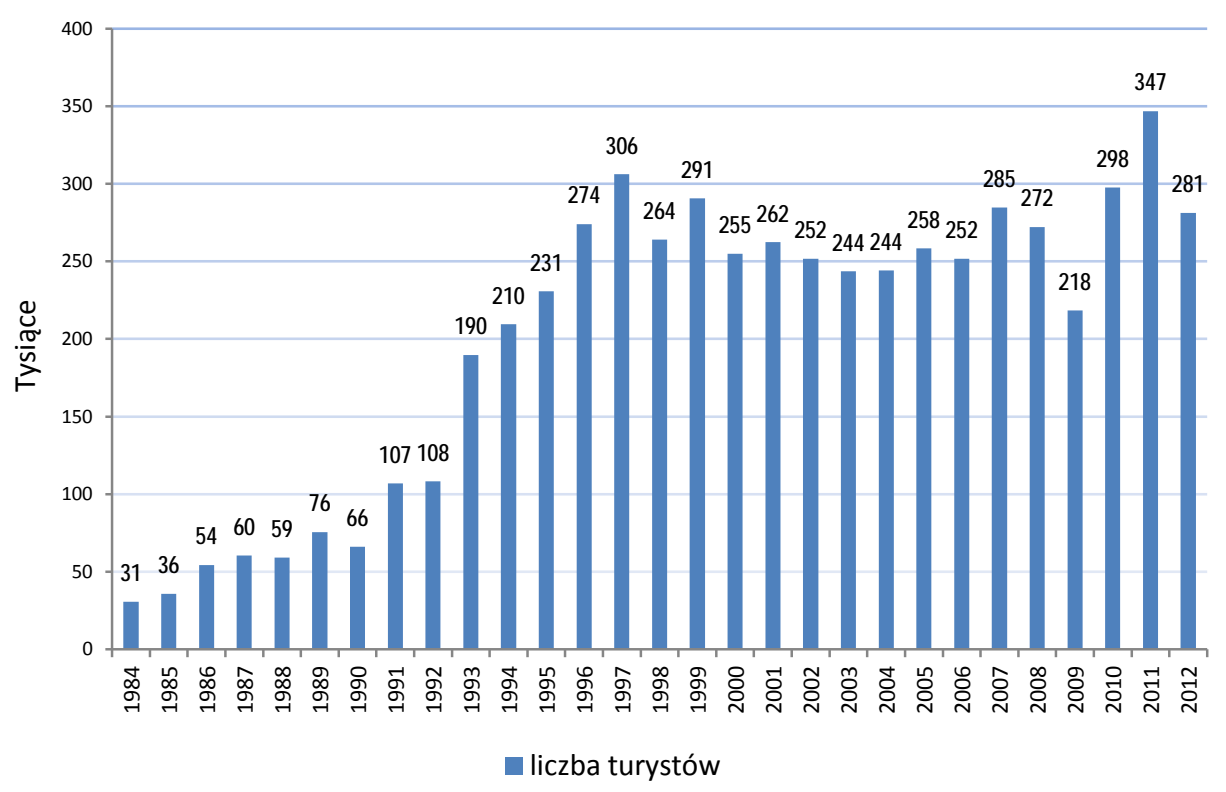

Rys. 9. Liczba turystów (w tys.) odwiedzających Park Narodowy Kenai Fjords w latach 1984-2012

Źródło: https://irma.nps.gov/Stats/Reports/Park; dostęp 04.12.2013

Fig. 9. Numbers of tourists visiting the Kenai Fjords National Park in the years 1984-2012

Source: https://irma.nps.gov/Stats/Reports/Park; access 04.12.2013

Obszar Narodowego Lasu Chugach (Chugach National Forest) obejmuje tereny południowo-centralnej część Alaski (rys.6), w skład których wchodzi znaczna część Prince William Sound, wschodnia część Półwyspu Kenai i delta rzeki Copper, co daje łączną powierzchnię prawie 28 tys. $\mathrm{km}^{2}$ (Land Areas of the National Forest System 2011). Obszar chroniony został utworzony w 1907 r. W jego skład wchodzą obszary leśne, lodowce, obszary podmokłe i $5600 \mathrm{~km}$ bardzo urozmaiconej linii brzegowej. W obrębie delty rzeki Copper znajduje się największy w pacyficznej strefie Ameryki Północnej kompleks bagien (Forest Facts, US Forest Service).

Lasy tu występujące zajmują bardzo wąski pas między wybrzeżem a strefą alpejską (z lodowcami zajmującymi 30\% powierzchni obszaru chronionego) i zaliczane są do deszczowych lasów strefy umiarkowanej (fot. 28), a w literaturze określane są także jako „subpolarne lasy deszczowe” (McKittrick 2011). Dominującymi gatunkami lasotwórczymi są świerk Sitka (fot. 29) oraz choina zachodnia i górska. 


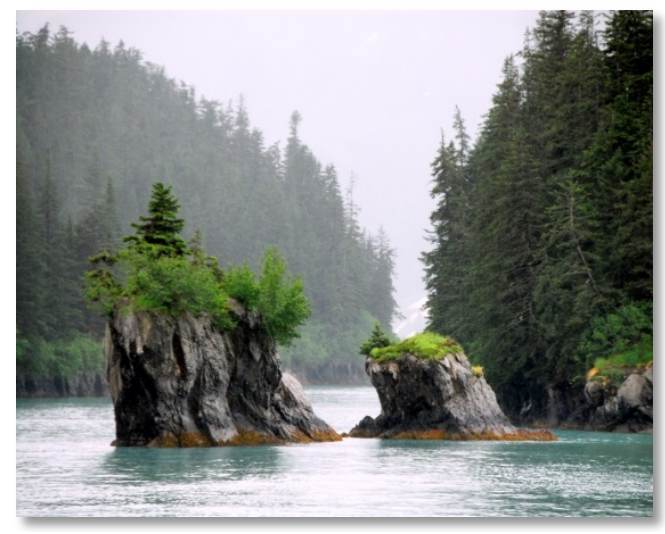

Fot. 28. Deszczowe lasy strefy umiarkowanej w Prince William Sound (fot. E. Papińska, 2013)

Photo 28. Temperate rain forests in Prince William Sound (photo: E. Papińska, 2013)

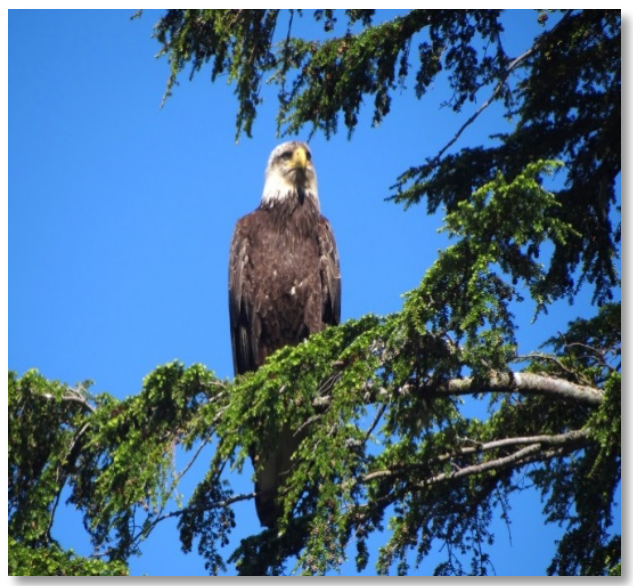

Fot. 30. Orzeł bielik amerykański Haliaeetus leucocephalus (fot. E. Papińska, 2013)

Photo 30. Bald eagle Haliaeetus leucocephalus

(photo: E. Papińska, 2013)

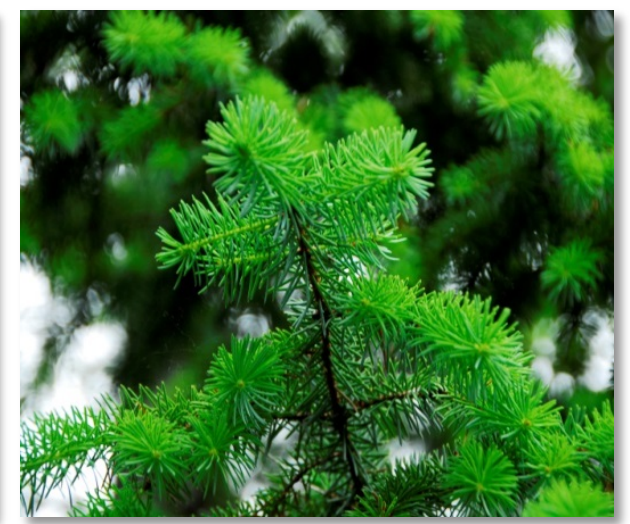

Fot. 29. Świerk Sitka Picea sitchensis (fot. E. Papińska, 2013)

Photo 29. Sitka Spruce Picea sitchensis (photo: E. Papińska, 2013)

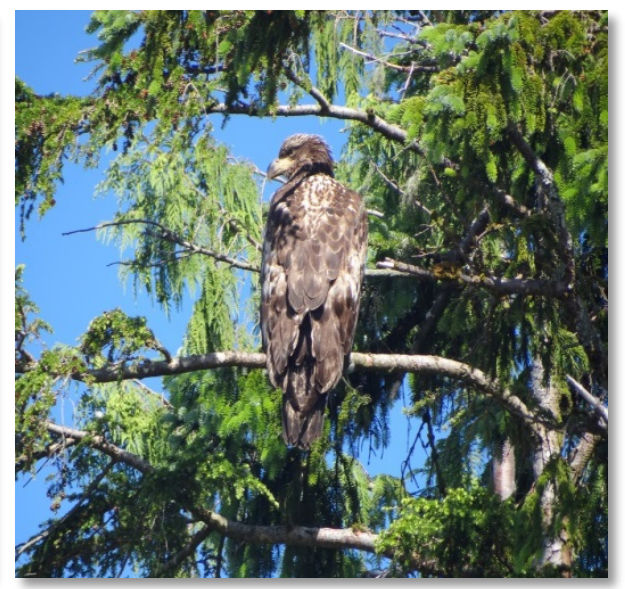

Fot. 31. Młody osobnik bielika amerykańskiego

(fot. E. Papińska, 2013)

Photo 31. Young bald eagle (photo: E. Papińska, 2013)

Cechą wyróżniającą ten obszar chroniony jest ogromne bogactwo fauny, zarówno lądowej, jak i morskiej. Tylko we wschodniej części Półwyspu Kenai znajduje się ponad 200 kolonii ptaków morskich. Populacja orła bielika 
(fot. 30, 31) szacowana jest na 3000 do 5000 osobników, to prawie tyle ile w pozostałych stanach USA razem wziętych. Na obszarze delty rzeki Copper schronienie znajduje ponad $20 \mathrm{mln}$ ptaków rocznie. Szacuje się, że około $1 / 4$ Światowej populacji łabędzia trąbiącego (Cygnus buccinator) i bernikli kanadyjskiej (Branta canadensis) ma w okresie letnim swoje obszary lęgowe na terenie delty.

W lasach obszaru chronionego żyją: łosie, karibu, jelenie czarnoogoniaste, kozice, niedźwiedzie czarne i grizzly. Jedynie w lasach tego rejonu spotkać można owce śnieżne (Dalla). Otaczające te rejony wody obfitują w bogactwo fauny. Występują tu m.in. lwy morskie (fot. 32), foki (fot. 33), wydry morskie (fot. 34, 35), humbaki. Tutaj także występuje pięć gatunków łososia pacyficznego: królewski, czerwony, różowy, srebrny i keta (chum salmon, Oncorhynchus keta).

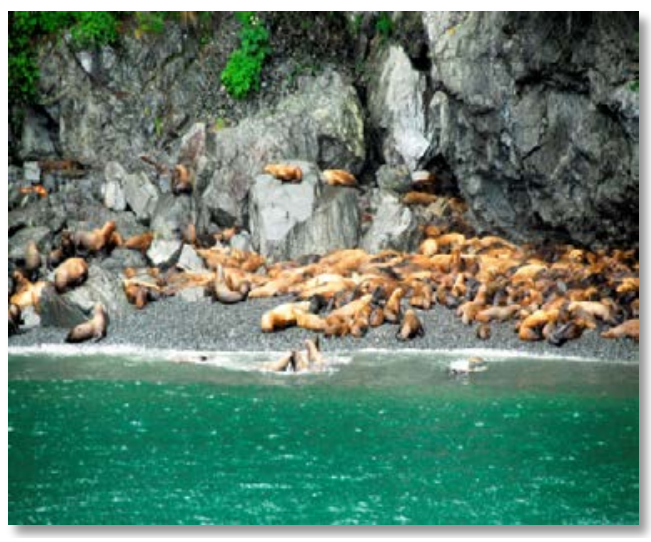

Fot. 32. Kolonia lwów morskich w Prince William Sound

(fot. E. Papińska, 2013)

Photo 32. Colony of sea lions in Prince William Sound

(photo: E. Papińska, 2013)

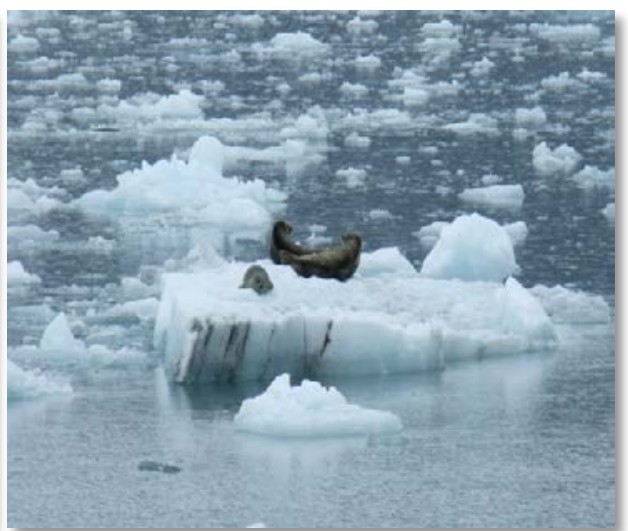

Fot. 33. Foki odpoczywające na górze lodowej w Prince William Sound (fot. S. Szczurtek, 2013)

Photo 33. Seals resting on the iceberg in Prince William Sound (photo: S. Szczurtek, 2013)

Także i na tym obszarze chronionym można obserwować lodowce, procesy glacjalne oraz formy z nimi związane. Jednym z ciekawszych i łatwo dostępnych lodowców jest Portage, położony w dolinie o takiej samej nazwie. Wody z topniejącego lodowca utworzyły jezioro, do którego uchodzi współczesny jęzor lodowcowy. Jeszcze na początku XX stulecia jego czoło znajdowało się znacznie dalej, wypełniał on całą obecną misę jeziorną (rys. 10). 


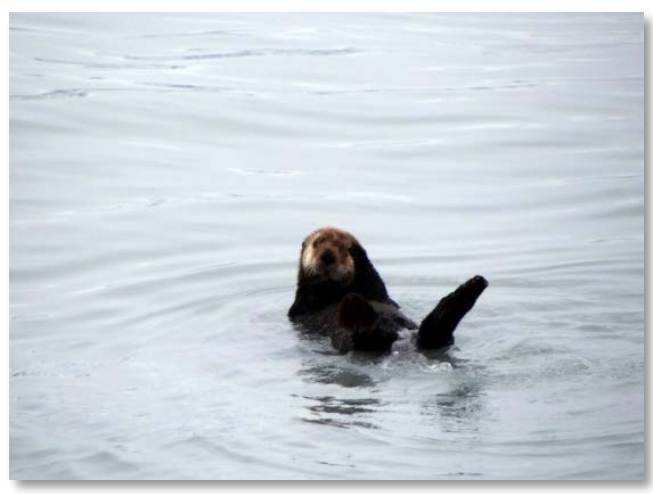

Fot. 34. Wydra morska, kałan, wydrozwierz Enhydra lutris (fot. E. Papińska, 2013)

Photo 34. Sea otter Enhydra lutris (photo: E. Papińska, 2013)

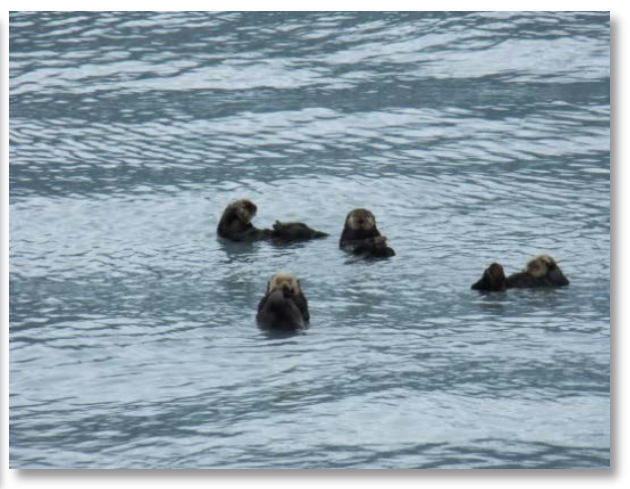

Fot. 35. Wydry w Prince William Sound (fot. S. Szczurtek, 2013)

Photo 35. Sea otters in Prince William Sound (photo: S. Szczurtek,, 2013)

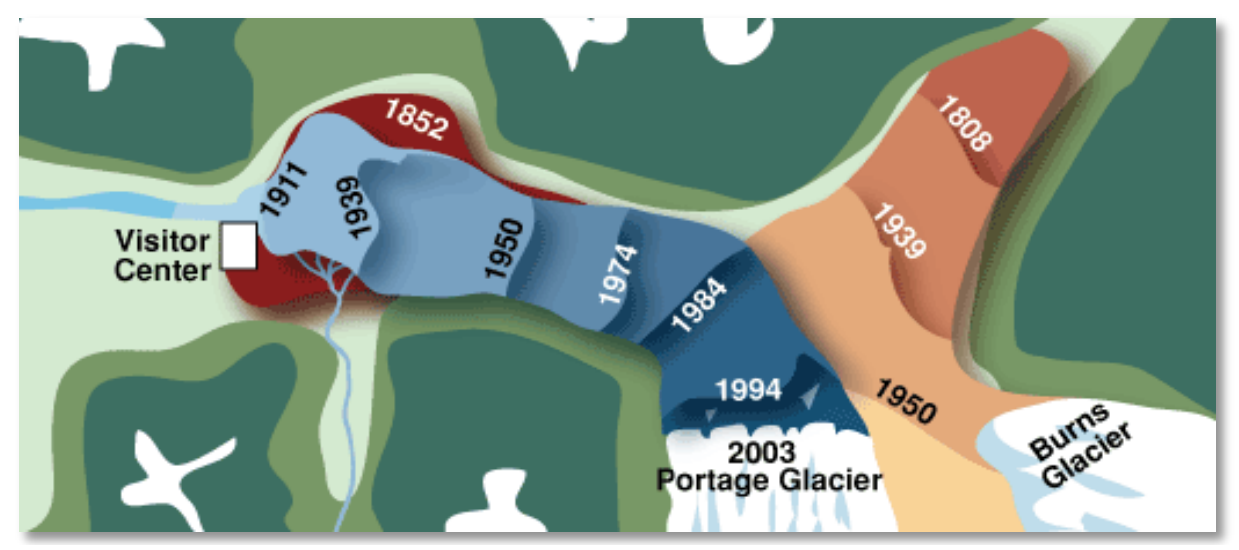

Rys. 10. Główne etapy zanikania lodowca Portage Źródło: http://www.fs.usda.gov/detail /chugach/home/ ?cid=stelprdb5251130; dostęp 07.12.2013

Fig. 10. The main retreat phases of Portage Glacier Source: http://www.fs.usda.gov/detail /chugach/home/ ?cid=stelprdb5251130; access 07.12.2013

Do czoła lodowca można podpłynąć kajakiem lub stateczkiem wycieczkowym, na pokładzie którego znajduje się strażnik z Chugach National Forest objaśniający procesy glacjalne. Przy odrobinie szczęścia turyści mogą zobaczyć cielenie się lodowca, co niezmiennie stanowi olbrzymią atrakcję (fot. 36-39). Stosunkowo bliska odległość, na którą podpływa się do lodowca powoduje także inne doznania. Można usłyszeć jego „mowę” - pomruki, odgłosy pękania, ścierania, huk odrywanych fragmentów lodowca i wiele innych. 


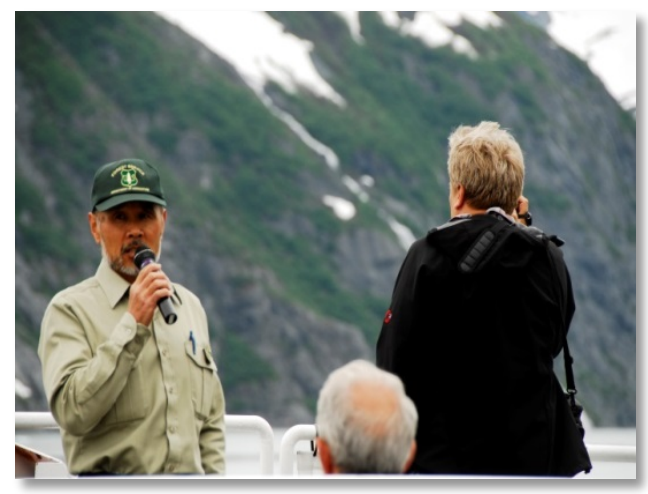

Fot. 36. Strażnik objaśniający turystom procesy glacjalne (fot. E. Papińska, 2013)

Photo 36. Ranger explaining glacial processes to tourists (photo: E. Papińska, 2013)

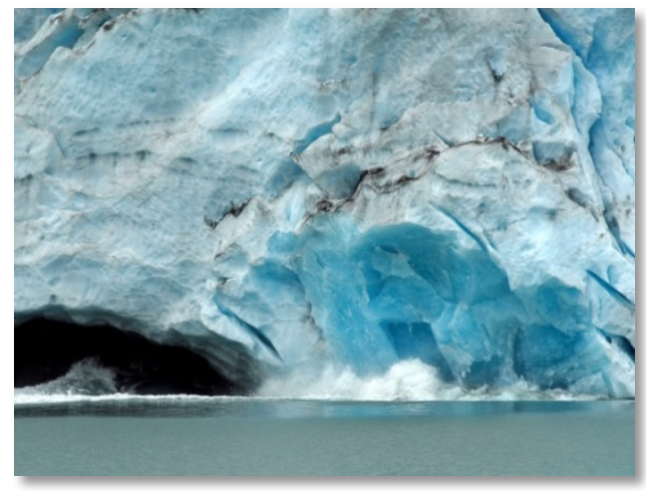

Fot. 38. Cielenie się lodowca Portage (fot. E. Papińska, 2013)

Photo 38. Calving Portage Glacier

(photo: E. Papińska, 2013)

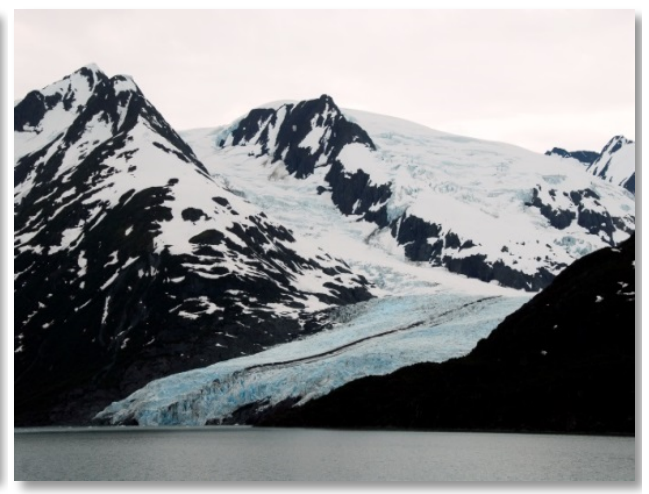

Fot. 37. Lodowiec Portage

(fot. E. Papińska, 2013)

Photo 37. Portage Glacier

(photo: E. Papińska, 2013)

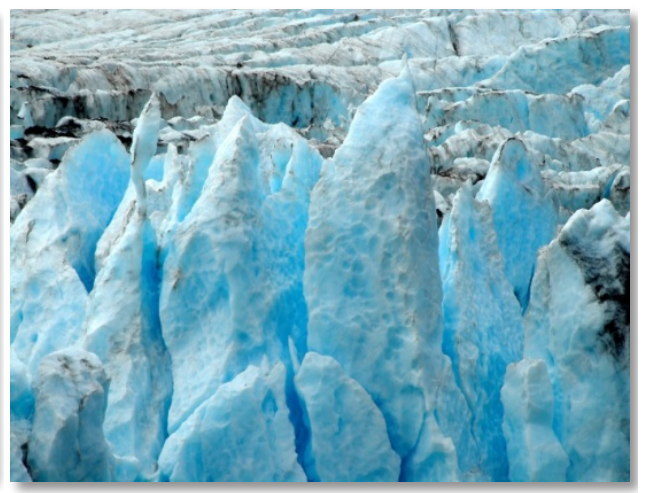

Fot. 39. Powierzchnia lodowca Portage (fot. E. Papińska, 2013)

Photo 39. Portage Glacier surface

(photo: E. Papińska, 2013)

Z miejscowości Seward i Valdez znajdujących się na terenie opisywanego obszaru chronionego, można popłynąć w krótkie rejsy, obserwując po drodze liczne fiordy, potężne lodowce, góry lodowe (fot. 40,41) oraz faunę i florę. Rejsy te cieszą się dużym zainteresowaniem turystów, nawet bez względu na dość kapryśne i trudne warunki atmosferyczne. Szacuje się, że rocznie obszar Chugach National Forest odwiedza ogromna rzesza turystów. Statystyka wejść na teren chroniony wykazuje ponad $7 \mathrm{mln}$ osób, ale jeden turysta może być liczony kilkakrotnie, gdyż rejestrowany jest w konkretnych punktach obszaru chronionego, gdzie znajdują się różnego typu atrakcje turystyczne i wejście jest zazwyczaj reglamentowane poprzez sprzedaż biletów, np. rejsy statkami w konkretne rejony. 


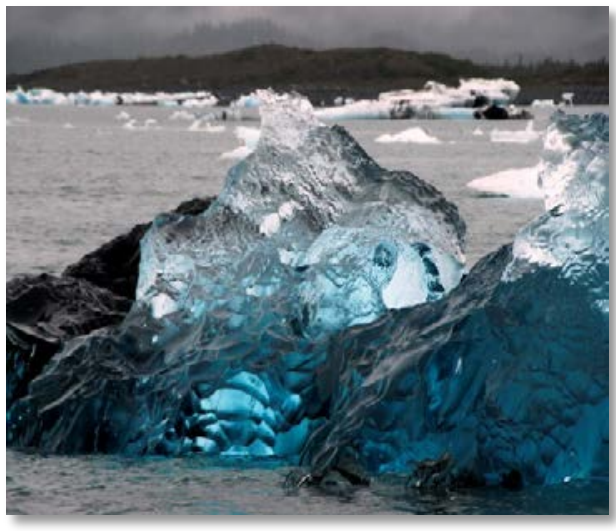

Fot. 40. Interesujące kształty gór lodowych w Prince William Sound (fot. E. Papińska, 2013)

Photo 40. Interesting shapes of icebergs in Prince William Sound (photo: E. Papińska, 2013)

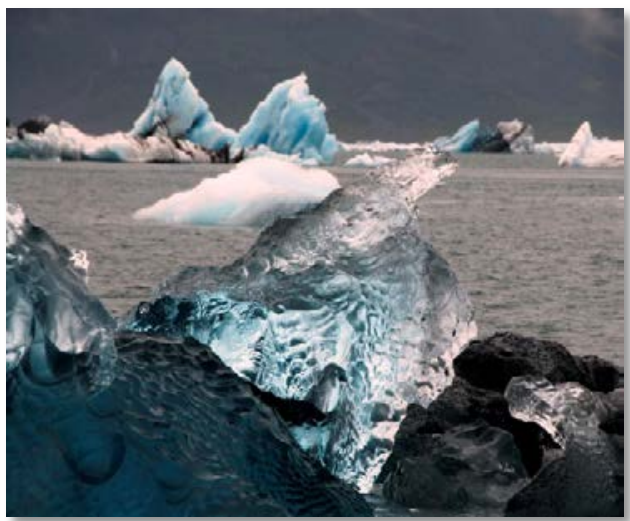

Fot. 41. Góry lodowe w Prince William Sound

(fot. E. Papińska, 2013)

Photo 41. Icebergs in Prince William Sound

(photo: E. Papińska, 2013)

\section{Podsumowanie}

Przedstawione $\mathrm{w}$ artykule wybrane walory przyrodnicze Alaski odwierciedlają jej ogromne zróżnicowanie środowiska. Niewątpliwie są one w stanie przyciągnąc na ten obszar turystów, którzy obcowanie $\mathrm{z}$ „dziką" naturą cenią sobie najbardziej. Tylko na terenie opisanych w artykule parków narodowych: Denali, Glacier Bay i Kenai Fjords, koncentruje się około 70\% ruchu turystycznego (rys. 11). W okresie 2003-2012 turyści odwiedzający Park Narodowy Denali stanowili od 22,4\% wszystkich turystów zarejestrowanych na Alasce (2009 r.) do 28\% (2004 r.). Jeszcze większy odsetek turystów odnotowano w Parku Narodowym Glacier Bay. W analogicznym okresie turyści odwiedzający ten Park stanowili 29\% w 2010 r., zaś 22\% w 2005 r. Nieco niższy jest odsetek turystów wjeżdżających na teren Parku Narodowego Kenai Fjords. W 2009 r. turyści ci stanowili 13,6\% ogółu turystów, zaś w 2011 r. 22,3\%. Tak duża koncentracja ruchu turystycznego na opisanych obszarach chronionych może dowodzić tezy, iż istniejące na ich terenach walory przyrodnicze stanowią dużą atrakcję turystyczną. Walory te w znacznej mierze wpływają na decyzje dotyczące wyboru obszaru recepcji turystycznej. 


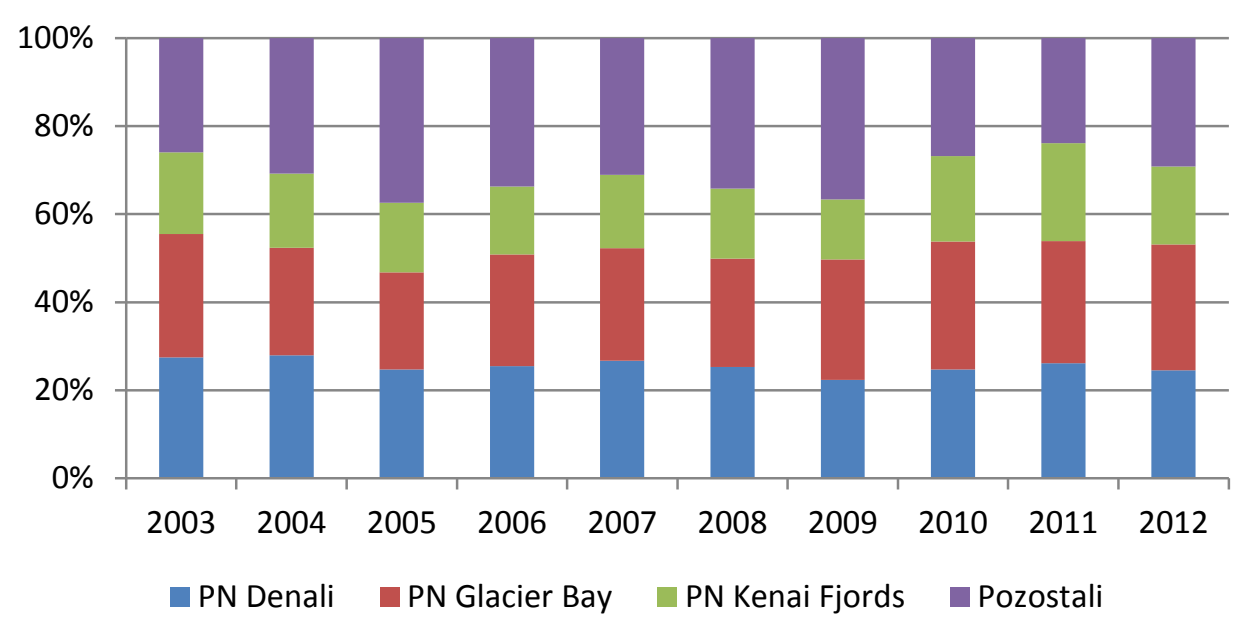

Rys. 11. Odsetek turystów odwiedzających wybrane parki narodowe Alaski w latach 2003-2012

Źródło: na podstawie danych https://irma.nps.gov)

Fig. 11. The percentage of tourists visiting selected national parks in Alaska in the years 2003-2012

Source: https://irma.nps.gov

Warto także podkreślić, że dostępność komunikacyjna do przedstawionych obszarów chronionych jest stosunkowo łatwa. Niewątpliwie także ten czynnik może w znacznej mierze wpływać na tak dużą koncentrację ruchu turystycznego na terenie scharakteryzowanych obszarów chronionych. Dotarcie w wiele atrakcyjnych miejsc wymaga od turysty niekiedy dość sporego wysiłku, choć dla niewykwalifikowanego turysty także przygotowana jest oferta turystyczna, chociażby w postaci rejsów oceanicznych z Vancouver lub Seattle (w kierunku północnym) oraz Whittier i Seward (w kierunku południowym).

Turyści na terenie Alaski mogą realizować różne formy turystyki kwalifikowanej: wspinaczkę lodową i górską, trekking, kajakarstwo, wędkarstwo, narciarstwo, rafting, wycieczki psimi zaprzęgami i wiele innych. Na obszarach chronionych prowadzonych jest wiele programów edukacyjnych, podczas których osoby w różnym wieku zapoznają się z ekosystemami Alaski w profesjonalny sposób, adekwatny do wieku. Tablice informacyjne w parkach narodowych dostarczają wielu ciekawych wiadomości także turystom indywidualnym. W ciekawy i prosty sposób można dowiedzieć się o procesach i zjawiskach fizycznych zachodzących na określonych obszarach, np. tempem deglacjacji lodowców.

Słabo rozwinięta baza noclegowa (ograniczone budownictwo ze względu na duże koszty związane z wieloletnią zmarzliną i stosunkowo krótki sezon letni, podczas którego są lepsze warunki atmosferyczne), wpływają na sposób 
penetrowania Alaski. O ile w południowej części infrastruktura hotelowa jest dość dobrze rozwinięta, to chcąc poznawać wnętrze Alaski trzeba albo zdecydować się na wynajęcie kampera lub z bardzo dużym wyprzedzeniem dokonać rezerwacji $\mathrm{w}$ nielicznych hotelach i motelach. W takiej sytuacji mobilny dom na kółkach wydaje się dość korzystnym rozwiązaniem.

Pierwszy pobyt autorki na Alasce nie dał pełnej satysfakcji poznawczej. Prawie miesięczny pobyt na Alasce nie był na tyle długi, aby nawet w pobieżny sposób spenetrować najciekawsze jej regiony. Ogromne przestrzenie i niebywała różnorodność procesów i zjawisk przyrodniczych powodują, że temu rejonowi należy poświęcić znacznie więcej uwagi.

\section{LITERATURA}

Alaska Visitor Statistic Program VI, Interim Visitor Volume Report, Summer 2012, McDowell Group, Inc., s. 1-10.

Alaska Visitor Statistic Program VI, Interim Visitor Volume Report, Fall/Winter 20122013, McDowell Group, Inc., s. 1-7

Bielak S.R., 2012, Parki narodowe i rezerwaty Alaski. Od Aleutów aż po bezdroża Arktyki, Podkarpacki Instytut Książki i Marketingu, Kraków, s. 146-157, 213-227.

Catton T., 2010, A Fragile Beauty: An Administrative History of Kenai Fjords National Park, National Park Service, http://www.nps.gov/kefj/historyculture/upload/A-Fragile-Beauty-AdminHistory-of-KEFJ.pdf, dostęp 06.12.2013.

Denali: The story behind the scenery, 1997, Wyd. 15 - 2012, KC PUBLICATIONS, INC.

Dziedzic E., 1998, Obszar recepcji turystycznej jako przedmiot zarzadzania strategicznego, Monografie i Opracowania, SGH, Warszawa, s. 9.

Forest Facts, US Forest Service, http://www.fs.usda.gov/detail/chugach/about-forest/ ?cid=STELPRDB5053239.

Gaworecki W., 2003, Turystyka, PWE, Warszawa, ss. 125.

Jelonek A., Soja M. (red.), 1996, Ameryka Północna. Encyklopedia Geograficzna Świata, OPRESS, Kraków, ss. 37.

Kaczmarek J., Stasiak J., Włodarczyk B., 2005, Produkt turystyczny, PWE, Warszawa, s. 51-57.

Kelley M., Simpson S., 2010, Glacier Bay National Park, Alaska, s. 114-119.

Kowalczyk A., 2001, Geografia turyzmu, Wydawnictwo Naukowe PWA, Warszawa, ss. 97.

Kożuchowski K., 2005, Walory przyrodnicze w turystyce i rekreacji, Wydawnictwo Kurpisz S.A., Poznań, s. 11-13.

Land Areas of the National Forest System, 2011, United States Department of Agriculture, http://www.fs.fed.us/land/staff/lar/LAR2011/LAR2011_Book_A5.pdf; dostęp 06.12.2913.

Lijewski T., Mikułowski B., Wyrzykowski J., 2002, Geografia turystyczna Polski, PWE, Warszawa, ss. 16.

Okołowicz W., 1969, Klimatologia ogólna, PWN, Warszawa, ss. 393. 
Rozen N., 1998, Harding Icefield's Loss is the Ocean's Gain, Alaska Science Forum, Article 1385., http://www2.gi.alaska.edu/ScienceForum/ASF13/1385.html, dostęp 06.12.2013.

\section{SUMMARY}

The State of Alaska is located in the north-western North America. Its area of $1717854 \mathrm{~km}^{2}$ is populated by 731449 people (as 2012). Population density is low, only 0.5 person per square $\mathrm{km}$. The main reason for the low population density are unfavourable natural conditions, the most important of which include climate, permafrost and topography.

Alaska's landscape diversity is a consequence of the variety of terrain types. For that reason, there are 8 national parks (Denali National Park, Gates of the Arctic National Park, Glacier Bay National Park, Katmai National Park, Kenai Fjords National Park, Kobuk Valley National Park, Lake Clark National Park, Wrangell-St. Elias National Park), national monuments and other lower rank protected areas established in Alaska. Each of these places, characterized by unique types of landscape (for example: glaciers, active volcanoes, fjords, high mountains) brings millions of tourists per year from the USA and all over the world. All these protected areas are very important for the development of tourist industry, and thus for the economy of USA. Alaska's national parks draw about 2 million visitors annually.

Keywords: Alaska, environmental values, national parks, tourism 